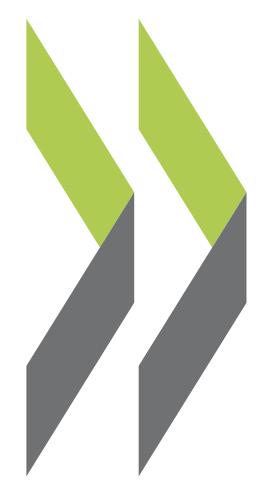

OECD Economics Department Working Papers No. 1266

$$
\begin{array}{r}
\text { Labour market reform } \\
\text { for more and better quality } \\
\text { jobs in Italy }
\end{array}
$$

Yosuke Jin,

\section{Patrick Lenain}


Organisation de Coopération et de Développement Économiques

Organisation for Economic Co-operation and Development

16-Nov-2015

ECONOMICS DEPARTMENT

English - Or. English

\section{LABOUR MARKET REFORM FOR MORE AND BETTER QUALITY JOBS IN ITALY}

ECONOMICS DEPARTMENT WORKING PAPERS No. 1266

By Yosuke Jin and Patrick Lenain

OECD Working Papers should not be reported as representing the official views of the OECD or of its member countries. The opinions expressed and arguments employed are those of the author(s).

Authorised for publication by Alvaro Pereira, Director, Country Studies Branch, Economics Department.

Document available in pdfformat only.

All Economics Department Working Papers are available at www.oecd.org/eco/workingpapers

Complete document available on OLIS in its original format

This document and any map included herein are without prejudice to the status of or sovereignty over any territory, to the delimitation of international frontiers and boundaries and to the name of any territory, city or area. 
OECD Working Papers should not be reported as representing the official views of the OECD or of its member countries. The opinions expressed and arguments employed are those of the author(s).

Working Papers describe preliminary results or research in progress by the author(s) and are published to stimulate discussion on a broad range of issues on which the OECD works.

Comments on Working Papers are welcomed, and may be sent to the Economics Department, OECD, 2 rue André-Pascal, 75775 Paris Cedex 16, France, or by e-mail to eco.contact@oecd.org.

All Economics Department Working Papers are available at www.oecd.org/eco/workingpapers.

The statistical data for Israel are supplied by and under the responsibility of the relevant Israeli authorities. The use of such data by the OECD is without prejudice to the status of the Golan Heights, East Jerusalem and Israeli settlements in the West Bank under the terms of international law.

\section{(c) OECD (2015)}

You can copy, download or print OECD content for your own use, and you can include excerpts from OECD publications, databases and multimedia products in your own documents, presentations, blogs, websites and teaching materials, provided that suitable acknowledgment of OECD as source and copyright owner is given. All requests for commercial use and translation rights should be submitted to rights@oecd.org 


\section{ABSTRACT/RÉSUMÉ \\ Labour market reform for more and better quality jobs in Italy}

A well-functioning labour market is indispensable to promote job creation, increase living standards, and develop a cohesive society. In Italy, the various deficiencies of the labour market have resulted in high unemployment, low labour force participation and job-skill mismatch. These deficiencies have contributed to the problem of allocation of resources, income distribution, and low productivity, reducing people's well-being. The current government, following on past governments' reforms, is introducing a package of labour market reforms - the Jobs Act - to improve the labour market in a consistent way. The reform will make the labour market more flexible and inclusive, and reduce duality. The long-lasting problem of effective enforcement will need to be overcome, with an increased focus on rapid implementation by the current government. A set of well-designed institutions, not only labour market policies but also the education system and product market regulation, would encourage higher labour force participation, especially among women, and produce more and better quality jobs in a more skill-intensive economy.

This Working Paper relates to the 2015 OECD Economic Survey of Italy (www.oecd.org/eco/surveys/economic-survey-italy.htm).

Keywords: labour market reform, turnover, skills, productivity, innovations, entrepreneurship

La réforme du marché du travail pour des emplois plus nombreux et de meilleure qualité en Italie

Un marché du travail qui fonctionne bien est indispensable pour promouvoir la création d'emplois, augmenter les conditions de vie, et développer une société prospère. En Italie, les diverses lacunes du marché du travail ont abouti à un chômage élevé, une faible participation au marché du travail et une inadéquation des compétences sur le marché du travail. Ces déficiences ont contribué au problème de la répartition des ressources et des revenus, et de la faible productivité, qui contribuent à réduire le bien-être du peuple. Le gouvernement actuel, suite aux réformes des gouvernements passés, est en train d'introduire un ensemble de réformes du marché du travail - appelé le «Jobs Act» - afin d'améliorer le marché du travail de manière cohérente. La réforme rendra le marché du travail plus flexible et inclusif, et réduira la dualité. Assurer une exécution efficace des reformes, un problème de longue durée en Italie, devra être surmonter, avec un accent sur la mise en œuvre rapide des reformes par le gouvernement. Un ensemble d'institutions bien conçues, non seulement les politiques du marché du travail mais aussi le système d'éducation et la réglementation du marché de produits, encourageraient une participation plus élevée de la population active, surtout chez les femmes, et produira des emplois plus nombreux et de meilleure qualité dans une économie exigeante qui est de plus en plus axée sur les compétences avancées.

Ce Document de travail se rapporte à l'Étude économique de l'OCDE de l'Italie 2015 (www.oecd.org/fr/eco/etudes/etude-economique-italie.htm).

Classification JEL: E2, E24, J01, J08, J6

Keywords: réforme du marché du travail, turnover, compétence, productivité, entrepreneuriat 


\section{TABLE OF CONTENTS}

LABOUR MARKET REFORM FOR MORE AND BETTER QUALITY JOBS IN ITALY ..................... 6

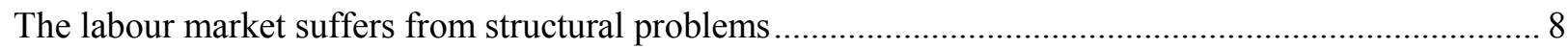

The government's labour market reform package: will it work? .......................................................... 14

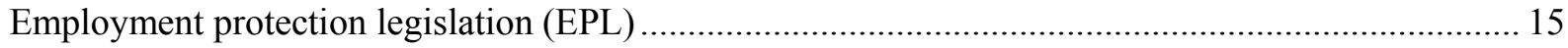

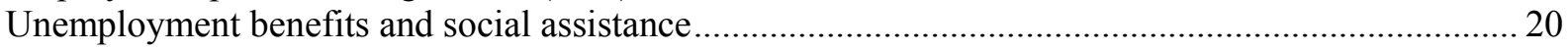

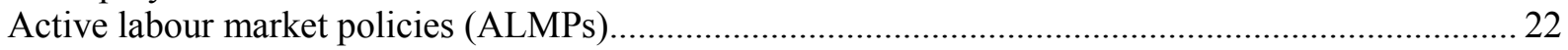

More and better quality jobs in a dynamic and inclusive economy ...................................................... 28

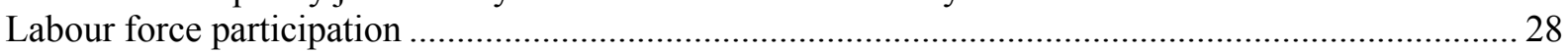

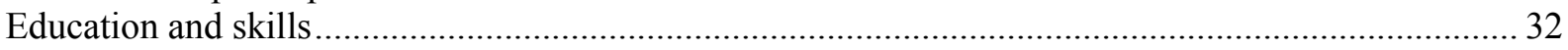

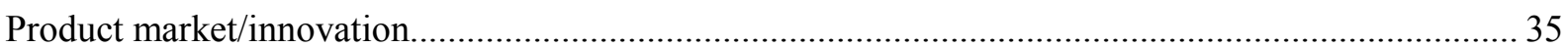

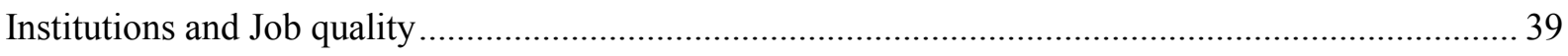

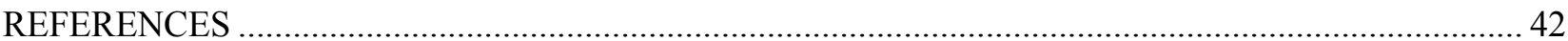

\section{Tables}

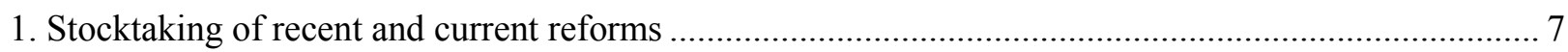

2 Recent reforms easing regulation on labour market contracts in selected countries ............................. 19

3. Broad outcome measures of job quality and their subcomponents .................................................... 40

\section{Figures}

1. Italy's potential output has stagnated mostly due to weak productivity ............................................... 8

2. Unemployment is high and increasing especially among youth .................................................... 9

3.Labour force participation is low especially among women and older people ..................................... 10

4. Large differences in activity and unemployment across regions ...................................................... 11

5. Limited employment prospects for temporary workers ….............................................................. 12

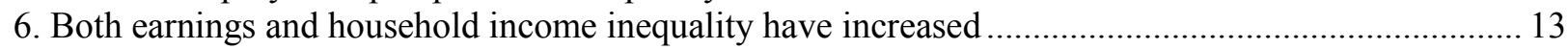

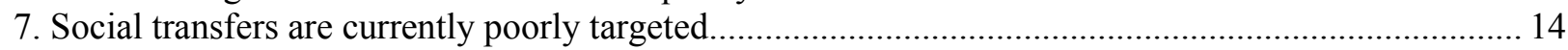

8. Employment protection legislation for permanent workers remains restrictive................................. 16

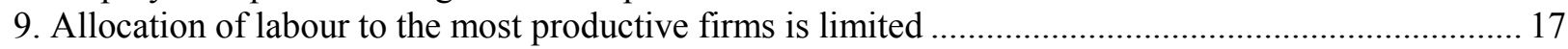

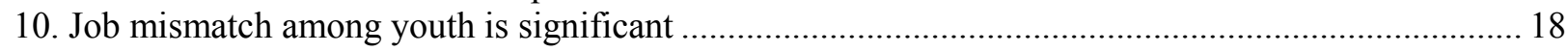

11. Net replacement ratio under the standard benefit close to the OECD average ............................... 21

12. ALMP spending is relatively low and concentrated on some categories ......................................... 23 
13. Labour market institutions affect wages for different categories................................................... 26

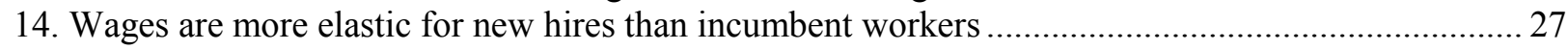

15. Tax wedge is high in Italy especially among low-income earners................................................... 30

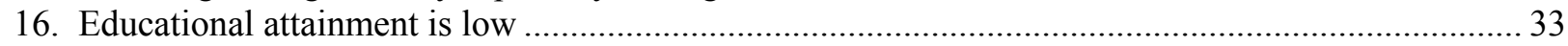

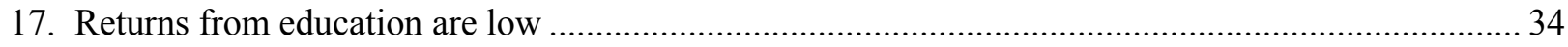

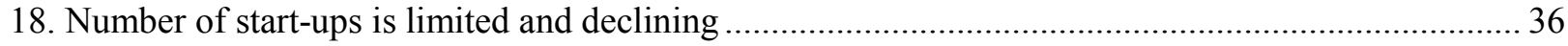

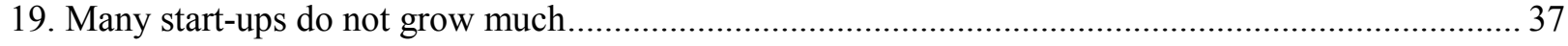

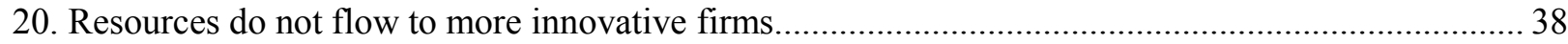

\section{Boxes}

Box 1. Employment Protection Legislation for different employment contracts before the reform........ 15

Box 2. Unemployment and social benefit system in transition ............................................................ 20

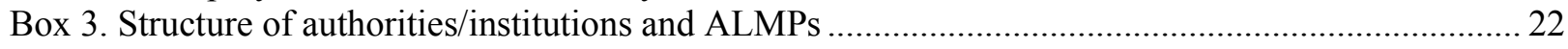

Box 4. Policy Recommendations for job creation and job quality ...................................................... 41 


\section{LABOUR MARKET REFORM FOR MORE AND BETTER QUALITY JOBS IN ITALY}

\section{By Yosuke Jin and Patrick Lenain ${ }^{1}$}

1. In Italy, unemployment is high, especially among youth, and labour force participation is low, notably among women and older people, particularly in southern regions. The mismatch between the supply and demand of skills is significant, in particular among youth. Labour productivity has stagnated for many years, but real wages in the aggregate have continued to increase, resulting in unit labour costs rising faster than in other countries. Income growth, however, has not been shared equally among workers, and the widening inequality of market income has been barely remedied by the redistribution system. The duality of the labour market, with around half of workers benefiting from stringent protection legislation and a significant minority having precarious or less protected jobs, has led to increased inefficiency and inequality.

2. The government is introducing a labour market reform package, the Jobs Act. It simplifies the different employment contracts, addresses the problem of labour-market duality, seeks to improve the income losses of job seekers, and strengthens activation policies. Successful labour market reform would promote more and better quality jobs and improve the distribution of the benefits of growth. Furthermore, a set of well-designed institutions, improving the quality of the labour force and stimulating entrepreneurial activities, would help to boost long-term prospects associated with better labour outcomes. The present chapter assesses how well the government's plans meet these needs and what further measures are necessary.

3. The main findings of this chapter are:

- In Italy, labour productivity has trended down since the mid-1990s. Institutional factors hamper a better allocation of resources and business incentives in general. The government is introducing a comprehensive labour market reform - the Jobs Act - and implementing successive reforms in the product market in order to unleash potential of Italian firms and workers.

- The Jobs Act will make the labour market more flexible by protecting individuals rather than specific jobs. Overall, employment protection legislation will be less stringent, facilitating job creation. The unemployment benefit system will be extended in association with enhanced support to job seekers (active labour market policies). These measures will encourage activity and reduce unemployment. The wage setting system should be more flexible, which would reinforce the beneficial effects from the Jobs Act.

- 4. In the medium- to long-term, labour force participation, the skill intensity of workers and entrepreneurship are key for higher and sustainable growth, but currently all these are weak in Italy. For the labour market to create more jobs, workers' skills should be enhanced and joboriented, and more quality-improving innovations and adoption of leading technologies would be required. This will be facilitated by a better reallocation of resources.

1. The authors are in the Economics department. This paper was originally prepared for the OECD Economic Survey of Italy published in February 2015 under the authority of the Economic and Development Review Committee. The authors are grateful to Alvaro Pereira, Robert Ford, other colleagues in the OECD and several Italian government officials for valuable discussions, comments and suggestions on earlier drafts. Special thanks go to Hermes Morgavi for research assistance and Brigitte Beyeler for assistance in preparing the document. 
Table 1. Stocktaking of recent and current labour market reforms

\section{Pension reform}

All age requirements and the contribution requirements for full pension to be linked to life expectancy. The required contribution period to obtain full pension are currently 42 years and 3 months for men and 41 years and 3 months for women which will continue to be increased in line with life expectancy.

\section{A comprehensive labour market reform ("the Fornero reform")}

Relaxation of employment protection rules on permanent contracts, notably limiting the possibility of reinstatement following unfair dismissal (see Box 1).

Reshaping incentives to hire on fixed-term contacts; no justification required for the first fixed-term contract (duration: no longer than one year); the interval period between two fixed-term contracts was extended.

Restricting atypical labour contracts (many of them out of the social security system, such as "collaboration").

New unemployment benefit (Assicurazione Sociale per l'Impiego, "ASpl"), unifying the standard unemployment benefit and a specific benefit following collective dismissal (CIG severance pay, see Box 2).

Introduction of "Mini-ASpl", a benefit for those with shorter contribution records, thus extending the unemployment benefit coverage to temporary workers.

\section{Adoption of Italian Youth Guarantee plan}

2013

Ensuring good-quality offers of employment, continued education, and an apprenticeship or a traineeship.

Setting up a Struttura di missione to harmonise active labour market policy designed and implemented at local level.

\section{A comprehensive labour market reform - The Jobs Act}

Liberalisation de facto of standard fixed-term contracts (provided that the maximum duration of successive contracts is no longer than three years).

Simplification of administrative procedures and requirements (for e.g. declaration of labour contracts). Tax refund for low-paid workers in 2014, which will be extended to 2015.

\section{Launch of Italian Youth Guarantee program (May 2104)}

\section{A comprehensive labour market reform - The Jobs Act}

Introduction of a new standard employment contract: less rigid dismissal protection than the current open-ended contract.

More universal unemployment benefits, integrating "ASpl" and "mini-ASpl" under consistent eligibility requirements, with its coverage extended to all workers (minimum contribution records required).

2014 -On-going and/or planned
Phasing out most of the Cassa Integrazione extensions (“CIG", wage supplementation for short-time working scheme, see Box 2).

A pilot programme of social assistance (Sostegno per I'Inclusione Attiva, "SIA"), targeted to households of specific categories, possibly extended to more households in poverty.

Set-up of the National Employment Agency, responsible for an efficient conditionality approach for provision of unemployment benefits (mutual obligation) and for harmonisation of ALMPs across regions.

Introduction of a legal minimum wage on an experimental basis. 


\section{The labour market suffers from structural problems}

5. In Italy, both labour utilisation and labour productivity are low. Productivity has trended down since the mid-1990s (Figure 1), because of misallocation of resources and other challenges such as unfavourable innovation and business environment (OECD, 2013a). More specifically, potentially more productive firms cannot attract more resources and thus cannot grow, while less efficient firms - many of which are old and small - maintain resources and market share (Andrews et al., 2014). Weak prospective on business conditions associated with low labour productivity, in turn, does not encourage firms to create jobs.

Figure 1. Italy's potential output has stagnated mostly due to weak productivity

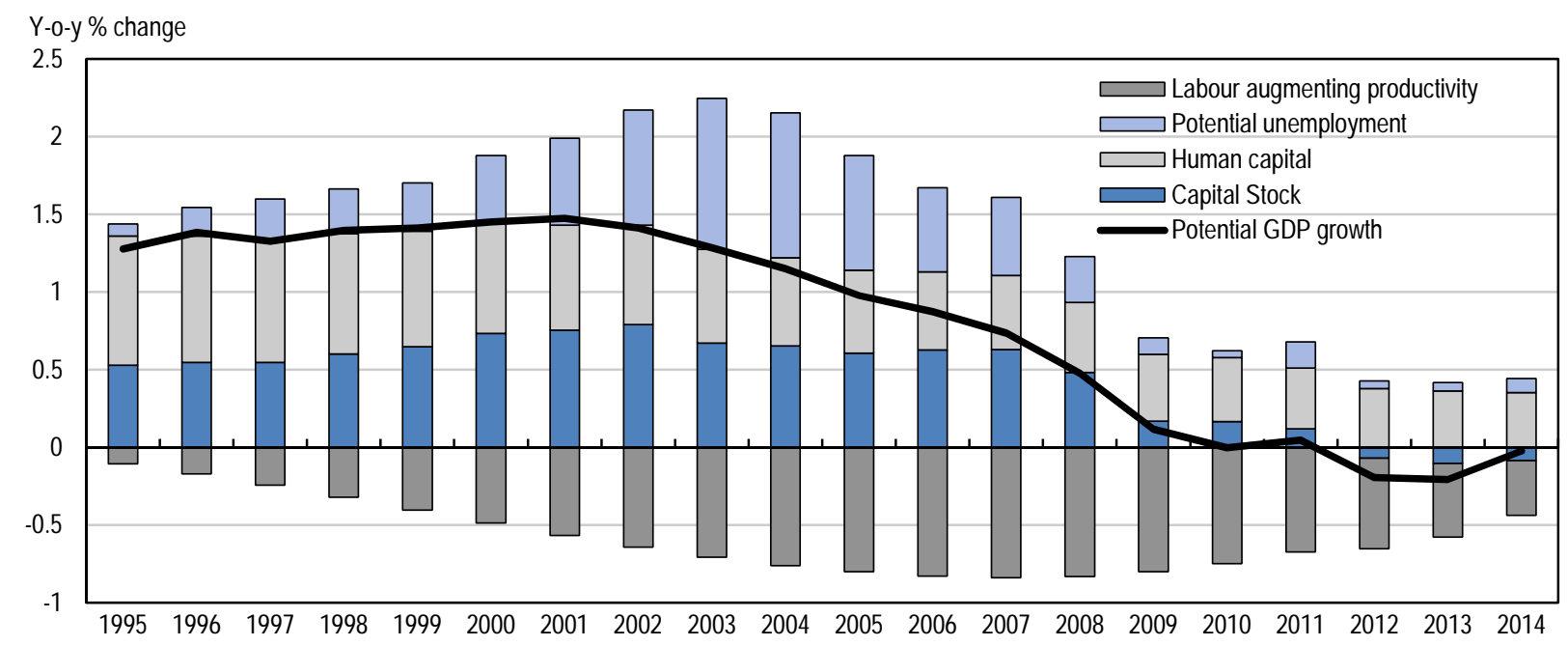

Source: OECD Economic outlook 96 database.

\section{Low labour utilisation}

6. The employment rate and the labour force participation rate have been low for a long time, especially in southern regions. The unemployment rate has increased to a high level by historical standards in mid-2014, when it reached $12.5 \%$. The youth unemployment rate is among the highest (Figure 2 ). The labour force participation rate remains low, although it has increased slightly in the past years. The female labour force participation rate is the third lowest (Figure 3). Labour force participation among older people has increased markedly but its level remains still well below the OECD average (Figure 3). High unemployment and low labour force participation are particularly prevalent in southern regions, possibly in association with weaker economic activities (Figure 4). A large number of workers are employed in the underground economy, estimated to be equivalent to $11.8 \%$ of total employment and concentrated especially in southern regions, according to estimates by Istat. 
Figure 2. Unemployment is high and increasing especially among youth

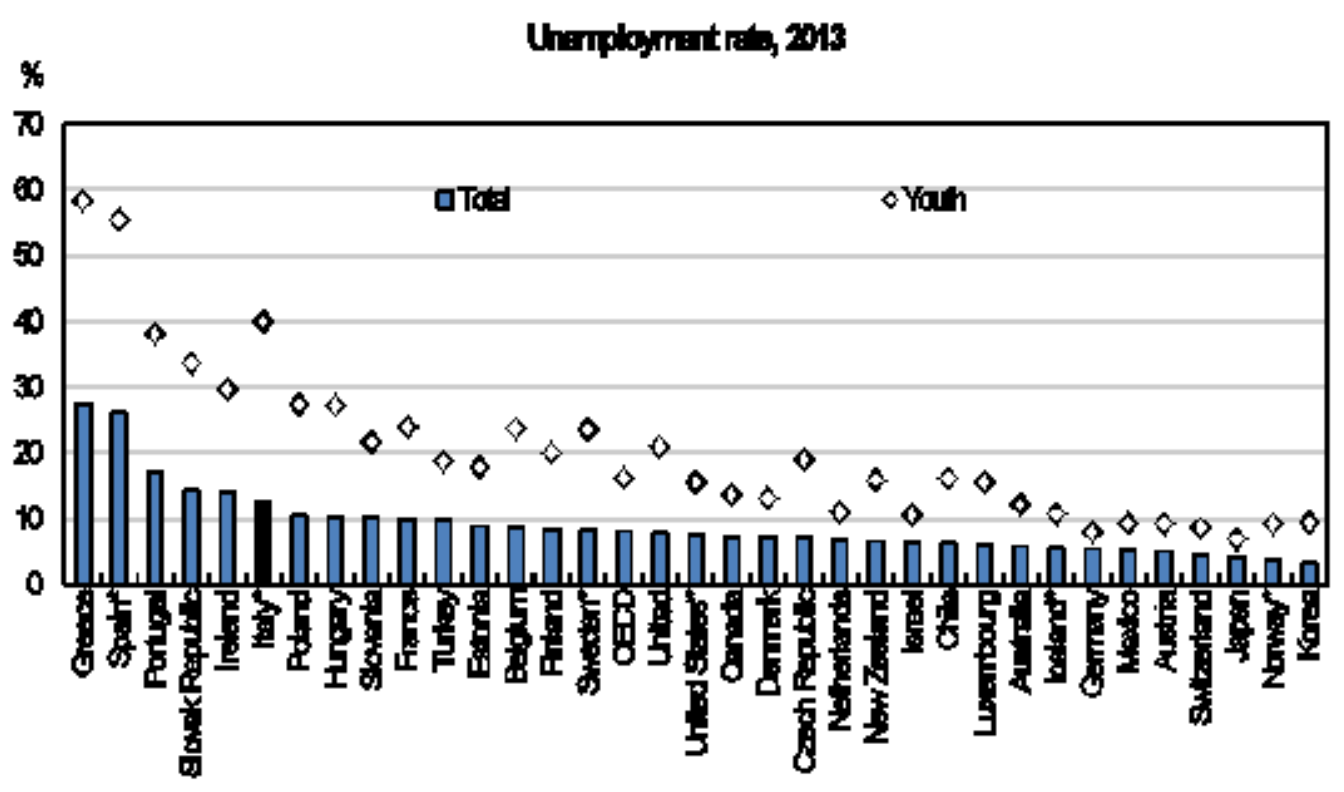

Note: Countries with *: the lower age limit is 16 instead of 15, for Iceland up to 2008, Italy after 2009, Norway up to 2005 and Sweden up to 2006. OECD: Weighted average.

Source: OECD (2014), OECD Employment Outlook 2014, OECD Publishing, Paris 


\section{ECO/WKP(2015)84}

Figure 3. Labour force participation is low especially among women and older people

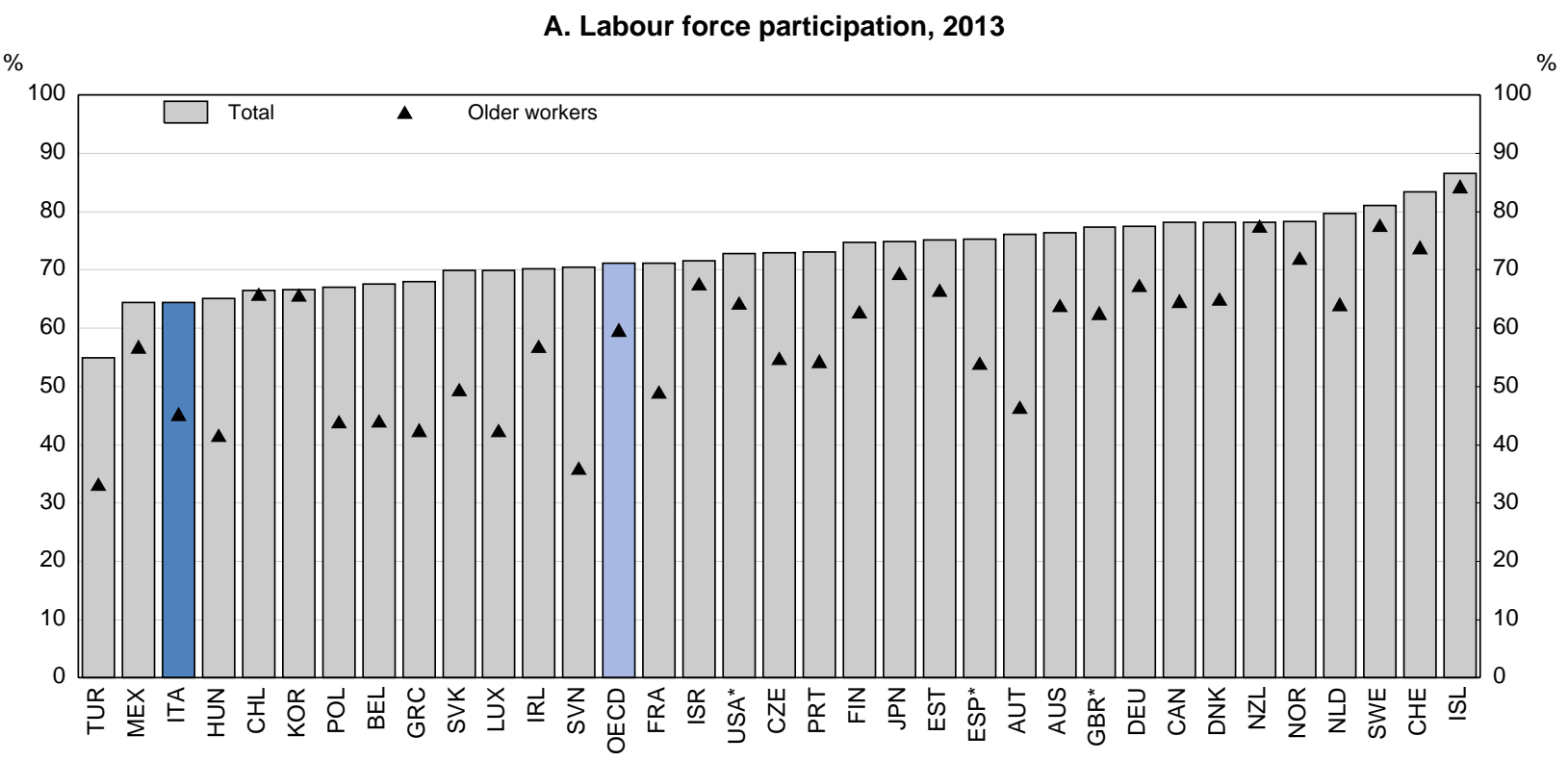

B. Labour force participation, 2013

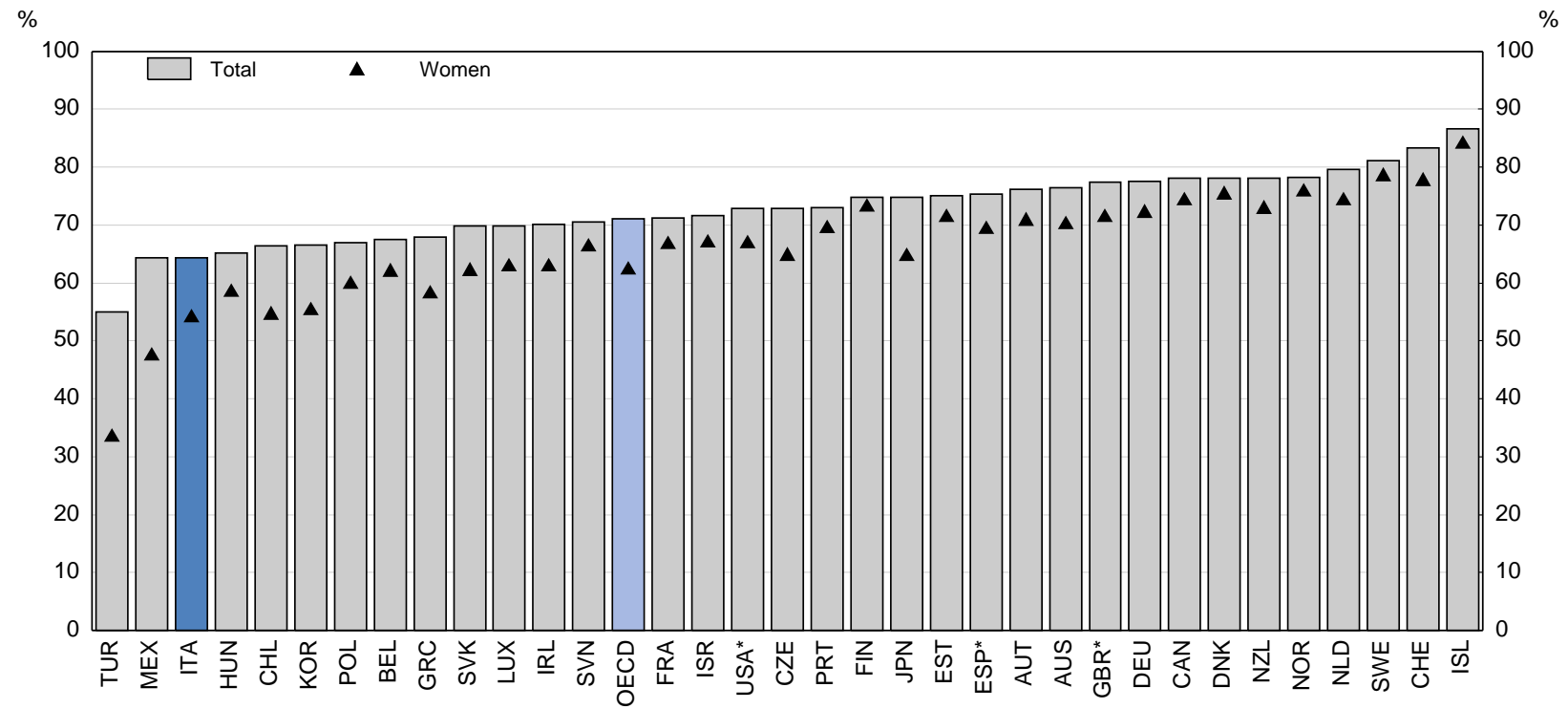

Note: Countries with *: the lower age limit is 16 instead of 15, for Iceland up to 2008, Italy after 2009, Norway up to 2005 and Sweden up to 2006. OECD: Weighted average.

Source: OECD (2014), OECD Employment Outlook 2014, OECD Publishing, Paris, 
Figure 4. Large differences in activity and unemployment across regions

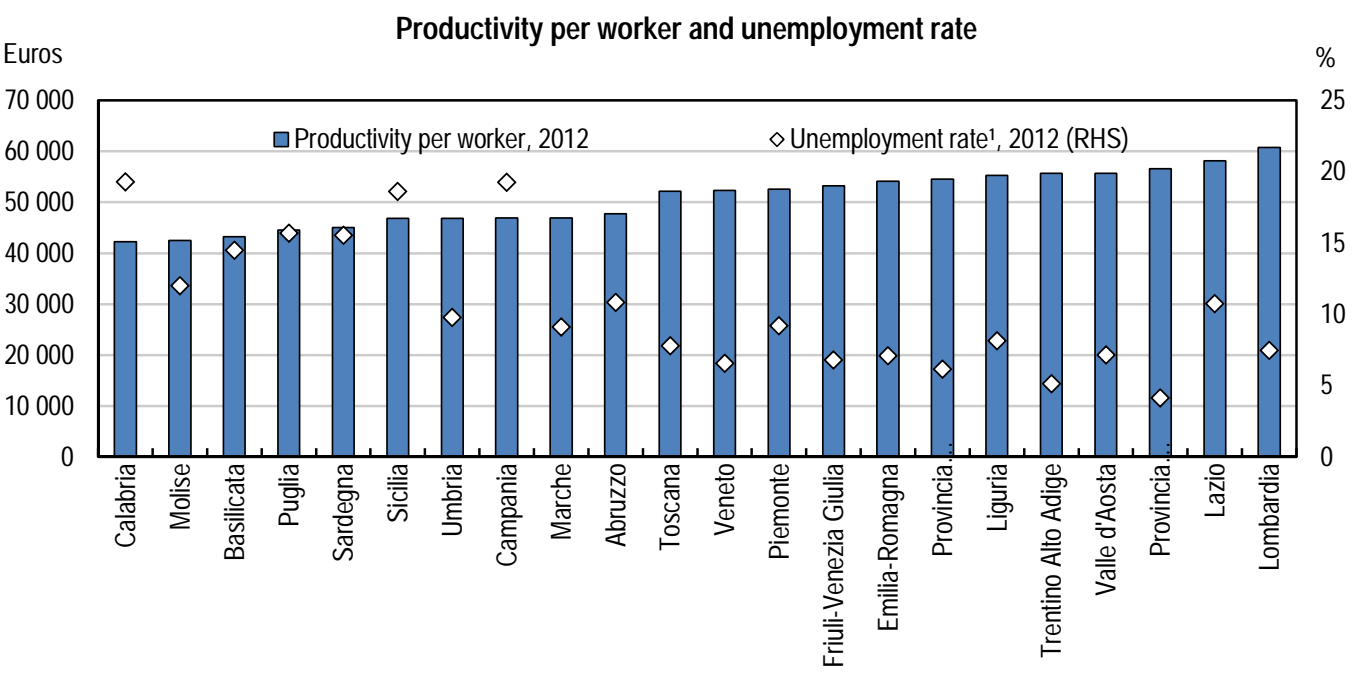

1. Age 15 and older.

Source: Regional Accounts, ISTAT.

7. The longer unemployment remains high, the greater the risk that long-term unemployment will persist, caused by damages to the skills and employability of job seekers (hysteresis effects). The structural unemployment rate is estimated to have risen from $8.0 \%$ in 2007 (just before the global crisis) to $9.0 \%$ in 2014 (OECD, 2014a). Currently, more than 50\% of the unemployed fall into the category of long-term unemployment - those who remain unemployed for more than one year. Those who remain unemployed for a long time tend to lose necessary skills and employability. Thus, unemployment due to cyclical weakness may become increasingly entrenched, leading to high rates of structural unemployment, which would continue to persist even after the economic recovery. According to OECD estimates, two out of three job seekers are likely to remain unemployed even when the economy will have fully recovered (Rusticelli, 2015).

8. The labour market is divided between those who are well-protected with open-ended contracts in large firms and those who are marginally attached with temporary or atypical contracts - the "duality" in the labour market. Flexible employment contracts have their merits because they facilitate the adjustment of the labour force when necessary, but these are known to increase job insecurity rather than to serve as a stepping stone for temporary workers (OECD, 2014b). Such jobs are disproportionately held by youth, especially less-educated and lower skilled workers and in most of the cases these jobs are not a voluntary choice (OECD, 2014b). According to Labour Force Survey data, nearly 15\% of workers are on flexible contracts and, among such workers, only a third will be able to obtain an open-ended contract three years later, while a quarter will be unemployed or have left the labour market (Figure 5). 
Figure 5. Limited employment prospects for temporary workers

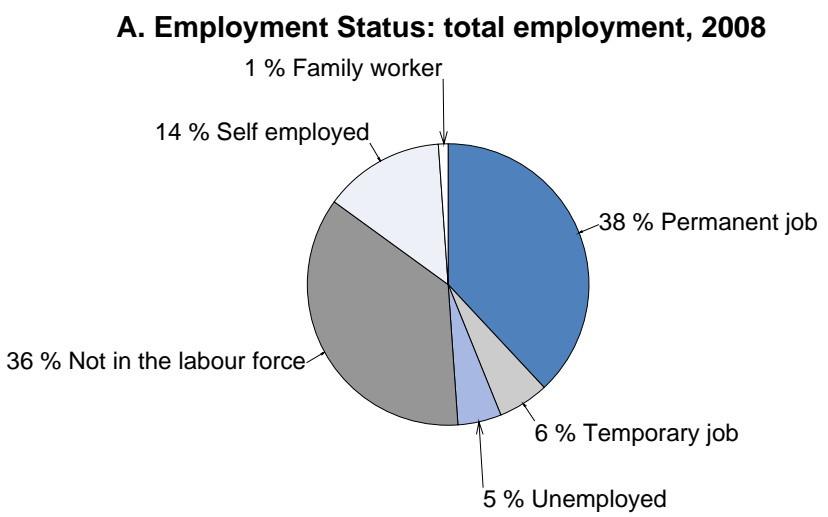

B. Employment Status as of 2011: temporary workers in 2008

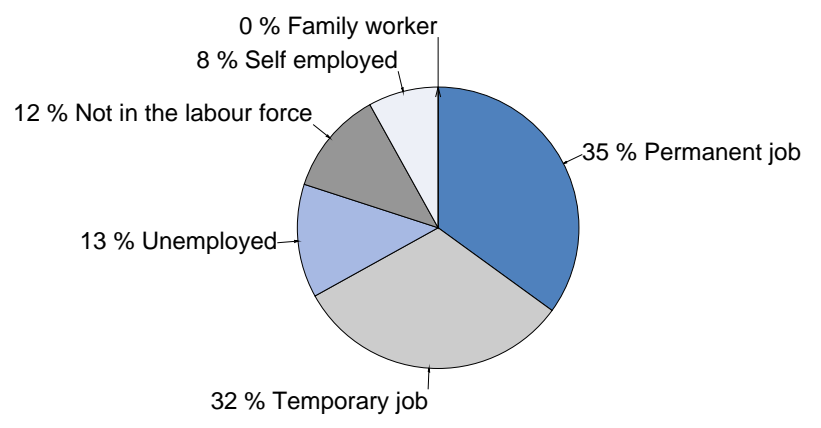

Note: The reported figures may be biased as it does not take in account of the distribution of the irregular workers (in the underground economy). ISTAT estimates that the number of such workers is equivalent to $11.8 \%$ of total employment.

Source: Eurostat EU-SILC (Community Statistics on Income and Living Conditions) survey.

\section{High labour costs}

9. Labour costs have evolved faster than labour productivity, reducing competitiveness. Wages responded little to a large labour slack, in contrast with other euro area countries facing financial stress. Italian firms have been the most reluctant to cut real wage in the OECD area, and this contrasts starkly with other financially-stressed euro area countries where incidence of nominal wage cuts has become more frequent (OECD calculations from Eurostat EU-SILC survey; OECD, 2014b). More wage flexibility would have facilitated the recovery while reducing the risk of hysteresis effects. These findings reveal some problems in the wage setting system.

10. Wage rises have not been shared equally among workers and market income inequality has continued to widen. During the crisis and recovery, real wage growth declined by $1 \%$ at the bottom decile of the earnings distribution (where the share of temporary workers is higher), while it increased by $1 \%$ at the median (OECD, 2014b). This occurred despite the predominance of labour adjustment at the margin, i.e. shedding temporary workers, which in isolation tends to bring up the average earnings at lower deciles. Also, many temporary workers do not necessarily work all year long. Against this backdrop, inequality in annual labour earnings has increased (Figure 6). 
ECO/WKP(2015)84

Figure 6. Both earnings and household income inequality have increased

A. Gini coefficient of household disposable income and gap between richest and poorest $10 \%$ in 2010
B. Percentage point change in the Gini coefficient disposable and market incomes between 2007-10

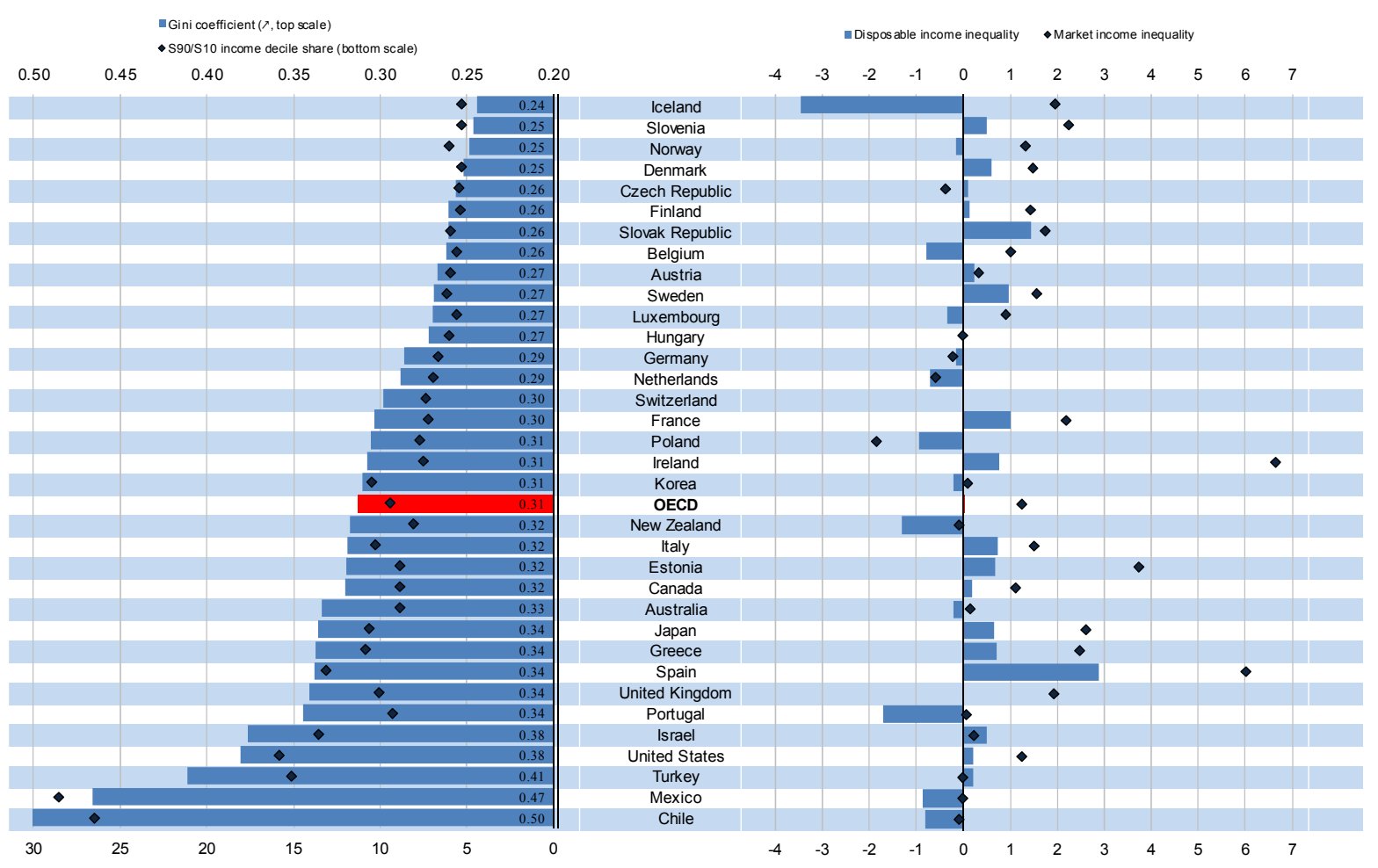

Note: Gini coefficients refer to 2009 for Hungary, New Zealand, Japan and Turkey, and 2011 for Chile instead of 2010, and to 2006 for Chile and Japan, 2008 for Australia, Finland, France, Germany, Israel, Mexico, New Zealand, Norway, Sweden and United States instead of 2007. Data for Switzerland are not available for 2007.

Source: OECD Society at a Glance 2014 (www.oecd.org/social/societyataglance.htm) Chapter 5, OECD Income Distribution Database, (www.oecd.org/social/inequality.htm).

\section{Household income inequality}

11. Net household income inequality has increased and the redistribution system has not been well designed to remedy it. As identified by a comprehensive OECD study on inequality (OECD, 2011a), labour earnings inequality as well as longer jobless spells contributed significantly to the overall inequality. In Italy, rising household income inequality has not been contained through the redistribution system. The unemployment benefit system has not been universal, excluding de facto workers with flexible employment contracts due to short tenure, and any non-contributory benefit (on account solely of low income) did not exist. Overall, Italy's social safety net is currently not well designed (Figure 7), though the needs for social assistance are increasing with the weak economic situation. 
Figure 7. Social transfers are currently poorly targeted

Average total cash transfers received by low- and high-income groups, percentage of average transfers in 2010 $\%$

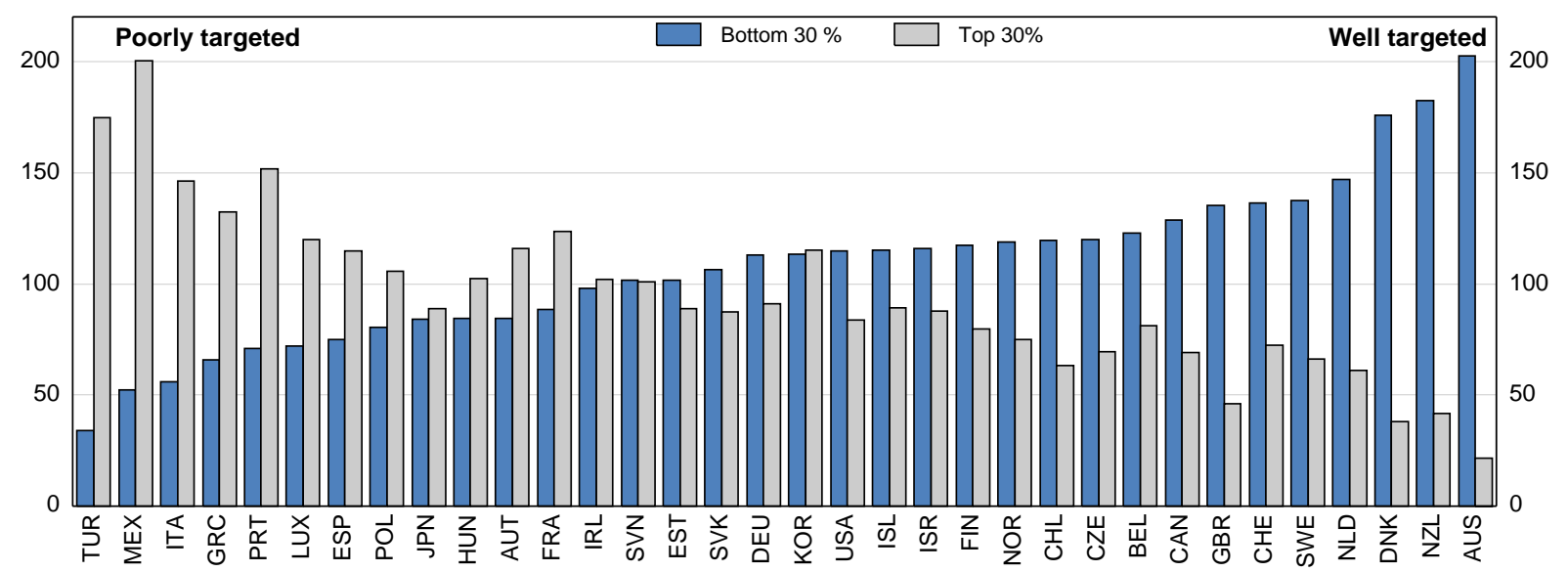

How to read the chart: In Portugal, the average total transfer payment received by low-income families (in the bottom $30 \%$ of the income distribution) is $71 \%$ of the average payment across all families, and less than half of the average benefit payment received by high-income families, who receive $52 \%$ more than the average family.

Note: Transfers include all social benefits. The reference year is 2009 for Hungary, Japan, New Zealand, Switzerland and Turkey. "Bottom 30\%" and "top 30\%" refer to average public transfers received by decile groups 1 to 3 and 8 to 10, respectively. Decile groups are determined in relation to household disposable income after accounting for taxes and transfers. All incomes and transfer amounts are adjusted for household size.

Source: OECD Society at a Glance 2014 (www.oecd.org/social/societyataglance.htm) Chapter 1, OECD Income Distribution Database, (www.oecd.org/social/inequality.htm).

\section{The government's labour market reform package: will it work?}

12. The government's programme for the labour market and social policy is broadly set out in the Jobs Act. The Act seeks to outline a number of broad objectives for the labour market, which the government will be entrusted to implement. It aims to go further than earlier reforms. Its broad orientation seems to be adequate and consistent: reforming employment protection legislation and its dualism, which would allow more efficient turnover, and extending social safety nets as well as strengthening activation policies, which would help people attached to the labour market. 
ECO/WKP(2015)84

\section{Employment protection legislation (EPL)}

\section{Box 1. Employment Protection Legislation for different employment contracts before the reform}

The OECD Employment Protection Legislation indicators present quantitative estimates of the degree of stringency of EPL in a comparable way across countries. The indicators take into account the relevant legislation, collective agreements and case law.

There are three broad categories: protection of permanent workers against individual dismissal, additional provisions for collective dismissals, and regulation on standard fixed-term contracts. These are also broken further into details, for instance the first broad category consists of: protection against unfair dismissal; notice and severance pay for no-fault individual dismissal and procedural inconvenience. Among them, protection against unfair dismissal, which is the major issue in this chapter, includes: definition of justified or unfair dismissal; length of trial period; compensation following unfair dismissal; possibility of reinstatement following unfair dismissal; maximum time for claim.

Concerning protection against unfair dismissal, definition of justified or unfair dismissal and compensation following unfair dismissal are found to be relatively more stringent for Italy (Figure 8); the former is due to the fact that dismissal for objective reasons (production and technological factors in the firm) is judged as unfair if a transfer and/or a retraining to adapt the worker to different work is not attempted prior to dismissal ("repechage"); the latter is because such compensation is equivalent to 21 months of salary for a worker at 20 years of tenure (a model case) against the OECD average of 6 months. For the case of smaller firms employing 15 or less employees, less strict provisions are in force.

The first two broad categories focus on stringency of EPL on dismissal of permanent workers whereas the last one on the readiness of the use of flexible types of employment contract. OECD (2014b) considers stringency of EPL on dismissal of temporary workers during the contract and finds that there are no significant differences and costs or restrictions in the case of termination at the end date do not exist in general. For Italy, the EPL indicator on fixed-term contracts has been reduced to the level closer to the OECD average, following the measures introduced in early 2014.

For details and comparison across countries, see Country Notes for OECD Employment Protection Legislation indicators.

In the case of redundancy parties must attend pre-trial conciliation organised by the Provincial Labour Office or through dispute settlement procedures set out in collective agreements. If no settlement is reached, the behaviour of parties in the conciliation stage is considered in court rulings. For details and comparison across countries, see Table 2, Annex 2.A2, Chapter 2 in OECD Employment Outlook 2013 (OECD, 2013b). 


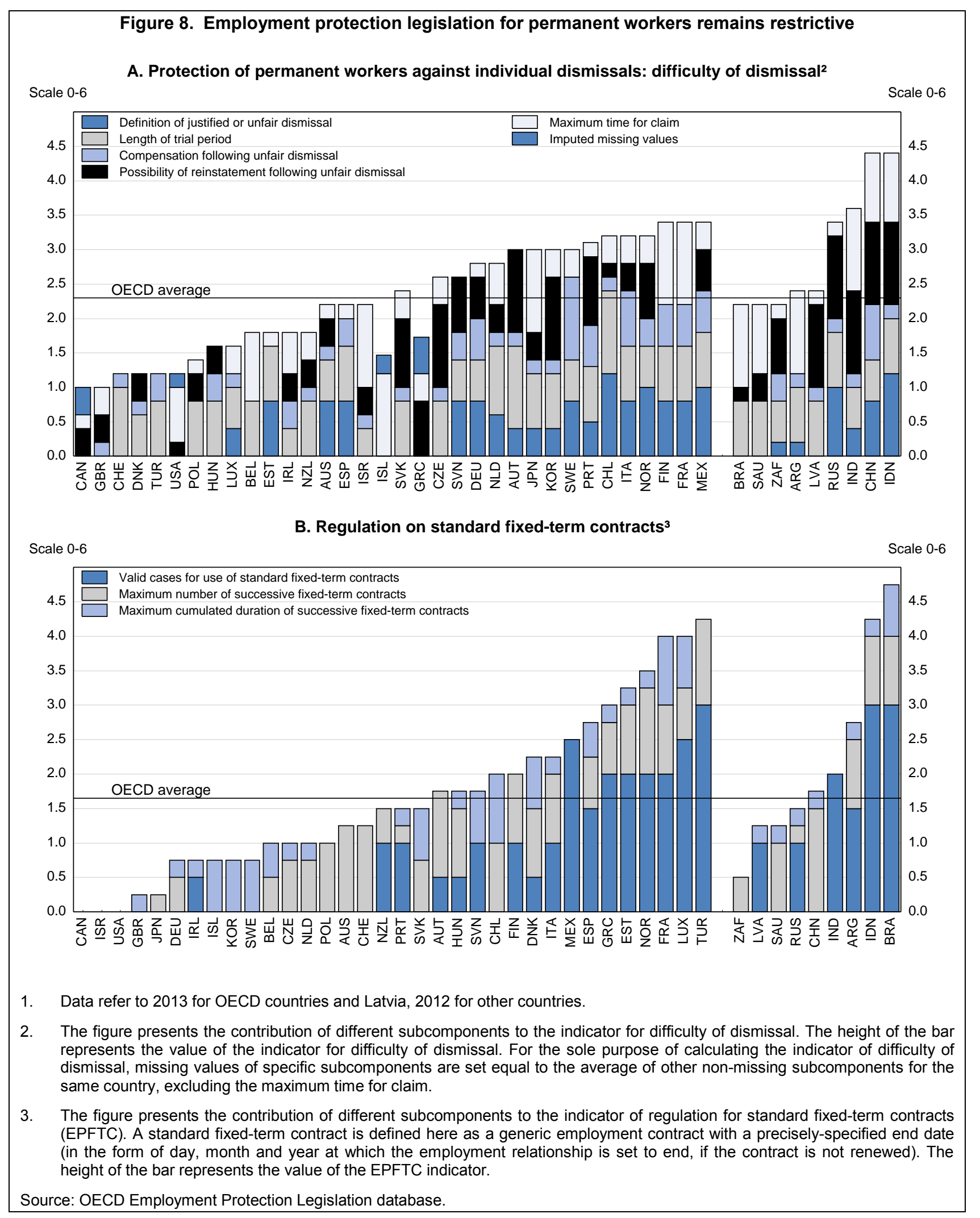


ECO/WKP(2015)84

\section{Why EPL matters?}

13. Strict EPL hampers efficient allocation of labour resources and induces unfavourable labour outcomes such as higher unemployment and lower productivity. By imposing costs on the firm to adjust its workforce, strict dismissal protection may inhibit efficient job separations and, indirectly, reduce efficient job creations (e.g. Mortensen and Pissarides, 1994; 1999). For Italy, Boeri and Jimeno (2005) empirically confirm such effects of employment protection on job turnover (see also similar findings by Schivardi and Torrini, 2008; Kugler and Pica, 2008). Low turnover matters especially when technological changes progress faster. Caballero et al. (2004), for example, find that countries with stricter EPL have slower rates of adjustment of productivity to long-run levels.

14. Italy has a problem of allocation of resources which can be evaluated in terms of the correlation between firms' productivity and their market share. Andrews and Cingano (2014) show that labour productivity in the Italian manufacturing industry is only around $10 \%$ higher than it would be if employment were allocated randomly across firms (Figure 9). They also show that this allocation problem is explained by institutional factors, including EPL along with product market regulations and bankruptcy regimes. For instance, according to their estimates, a reduction by 1 point (e.g. from 3.0 to 2.0 on the 0 to 6 scale used in Figure 8) in the OECD EPL indicator would improve labour productivity by around $6.5 \%$.

Figure 9. Allocation of labour to the most productive firms is limited

Covariance across firms between firm size and labour productivity; log points; manufacturing sector in selected OECD countries in 2005

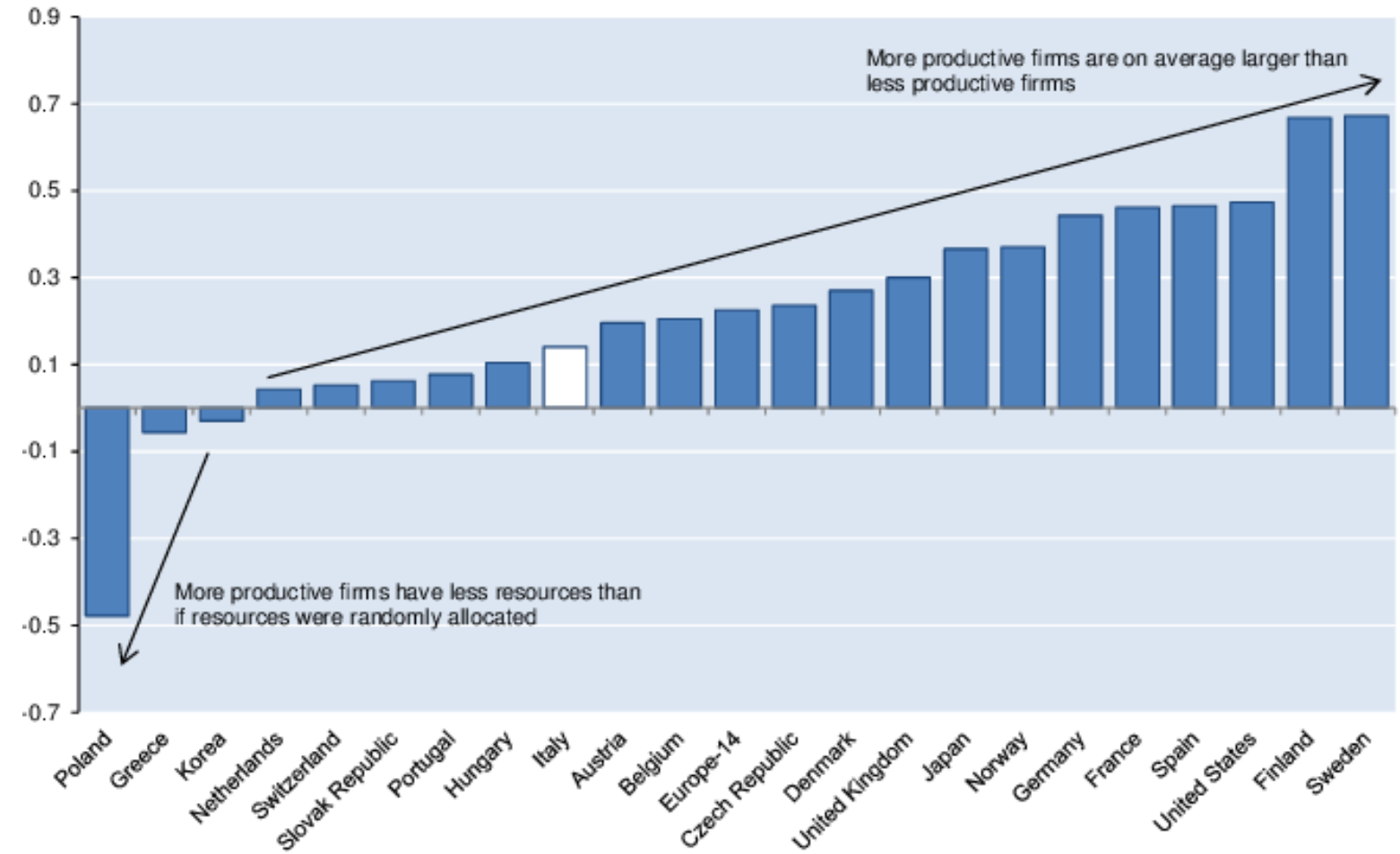

Note: The estimates show the extent to which the firms with higher than average labour productivity have larger employment shares. In most countries, the covariance between productivity and employment share is positive, suggesting that the actual allocation of employment boosts manufacturing labour productivity, compared to a situation where resources were allocated randomly across firms (this metric would equal zero if labour was allocated randomly). For example, manufacturing labour productivity in the United States is boosted by around $50 \%$ due to the rational allocation of resources. Europe-14 includes: Austria, Belgium, Czech Republic, France, Greece, Germany, Hungary, Italy, Netherlands, Portugal, Poland, Spain, Slovak Republic and Switzerland, and is obtained by aggregating the respective allocative efficiency indicators by each countries share in manufacturing sector employment.

Source: Andrews, D. and F. Cingano (2014), "Public Policy and Resource Allocation: Evidence from firms in OECD countries", Economic Policy 29(78), pp. 253-296. 
15. In the labour market, inefficient allocation of resources can be illustrated by job-skill mismatch. If more productive firms find it more difficult to attract skilled labour and gain market shares because less productive firms retain them, thus the share of over-skilled workers is high, then the reallocation mechanism is hampered. Adalet McGowan and Andrews (2015) find such job-skill mismatch as well as under-qualification (which reduces productivity in each firm) contributes to reducing overall productivity, especially in Italy (Figure 10). They also attribute this reallocation problem to institutional factors, including EPL.

Figure 10. Job mismatch and under-qualification are significant in Italy
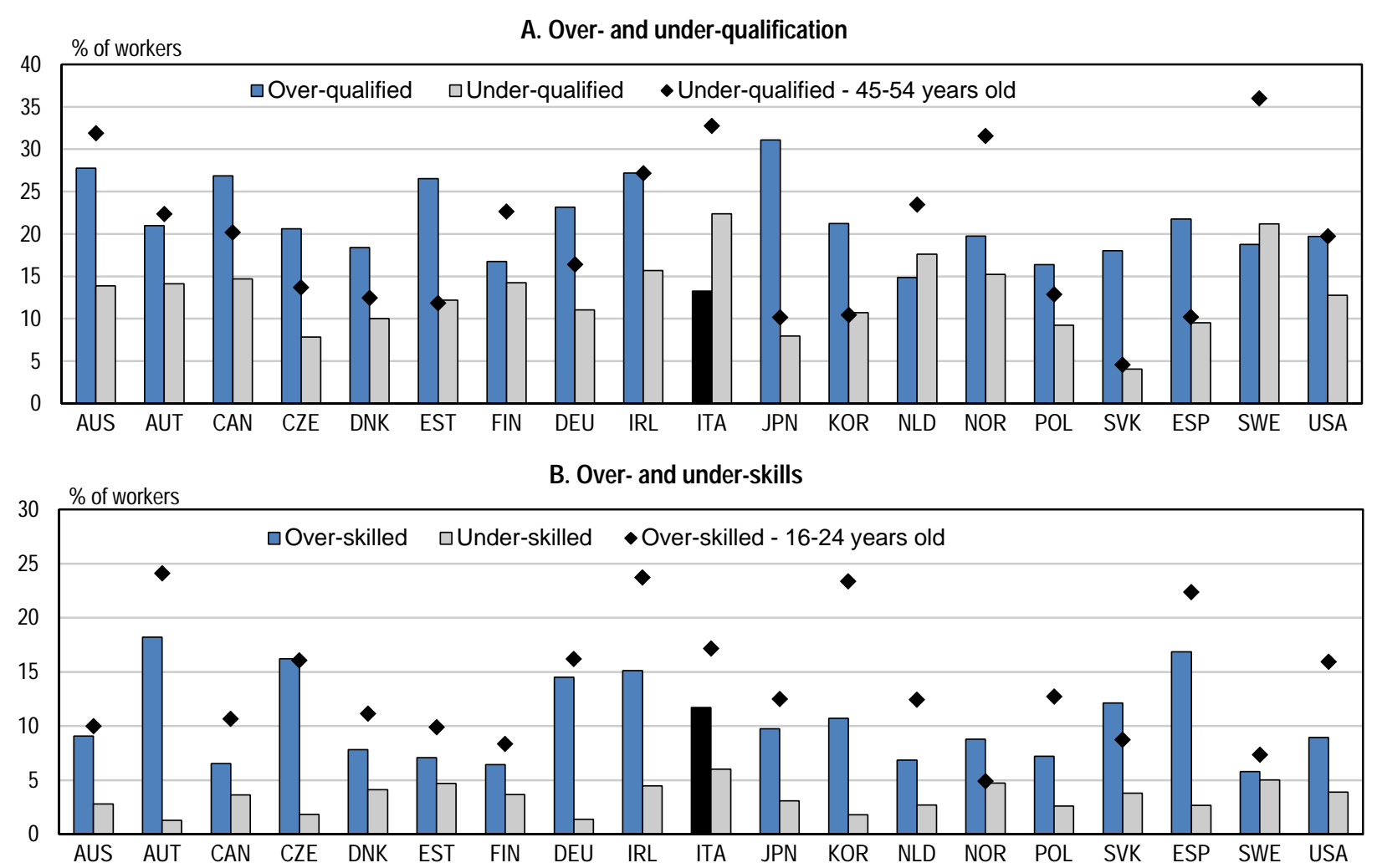

Source: OECD (2013), OECD Skills Outlook 2013: First Results from the Survey of Adult Skills, OECD Publishing, Paris, on the Survey of Adult Skills (PIAAC) 2012.

16. Legal risk and financial costs associated with unfair dismissal provisions have been identified as most burdensome and affecting gross worker flows in general (OECD, 2013b). For Italy, the OECD Employment Protection Legislation indicators which aggregate different aspects of EPL show that uncertainly on the decision of fair/unfair dismissal as well as monetary compensation following unfair dismissal are key problems (Box 1). The EPL indicators also show that regulation on fixed-term contracts is close to the OECD average, pointing to the remaining duality in the Italian labour market.

\section{A recent reform attempted to reduce dualism}

17. The government in place during 2011-13 introduced a wide-ranging reform to achieve a better balance of employment protection between permanent and temporary/atypical workers. It relaxed the protection of permanent workers, restricting the possibility of reinstatement following unfair dismissal (Table 2). It also introduced mandatory conciliation mechanism before lodging a complaint with courts, aiming at simplifying procedures for dismissal cases. 
ECO/WKP(2015)84

Table 2. Recent reforms easing regulation on labour market contracts in selected countries

\begin{tabular}{|c|c|c|c|c|c|c|}
\hline & ITA & ESP & FRA & GBR & GRC & PRT \\
\hline Reduce procedural inconvenience for dismissal cases & & $x$ & $x$ & & $\mathrm{x}$ & \\
\hline Reduce severance pay for permanent contracts & * & $x$ & & & $x$ & $x$ \\
\hline Relax the definition of unfair dismissal & & & $x$ & & & $x$ \\
\hline Reduce compensation for unfair dismissal & & $x$ & & & & \\
\hline Reduce possibility of reinstatement for unfair dismissal & $x$ & & & & & $x$ \\
\hline Reduce regulation on collective dismissals & $x$ & $x$ & $x$ & & $x$ & \\
\hline Reduce regulation on non-permanent contracts & $x$ & $x$ & & & $x$ & $x$ \\
\hline Increase regulation on non-permanent contracts & & & & $x$ & & \\
\hline
\end{tabular}

Note : The 2012 reform relaxed employment protection rules on permanent contracts, notably limiting the possibility of reinstatement following unfair dismissal. The 2012 reform reshaped incentives to hire on fixed-term contacts; no justification required for the first fixed-term contract if its duration does not exceed one year, which was extended to three years in early 2014 ; the interval period between two fixed-term contracts was extended, which was withdrawn in early 2014.

* There is no severance pay in Italy.

Source: OECD Secretariat's estimates.

18. As a result, the difficulty of dismissal procedures seems to have eased, although this has not so far provided the intended result of encouraging hiring of permanent workers. The frequency of reinstatement in case of unfair dismissal has been reduced as far as dismissal for objective reasons (motivo oggettivo, i.e. due to production and technological factors in the firm) is concerned. However, this has not yet resulted in encouraging firms to use open-ended contracts more widely: the number of new open-ended contracts has been decreasing while fixed-term contracts continue to account for a large share of labour turnover. The reduction in the use of atypical contracts has been the only visible outcome so far (Ministry of Labour, 2014).

\section{The Jobs Act streamlines labour contracts further}

19. The Jobs Act aims at simplifying and streamlining dismissal rules further. A substantial part of the Jobs Act will be introduced through the enabling law which passed through Parliament late 2014. A new standard contract with employment protection increasing with tenure was swiftly introduced after the adoption of the Law in late December 2014. The Jobs Act also limits further the possibility of reinstatement of workers following unfair dismissal, excluding this possibility for dismissal for objective reasons. It preserves access to courts in case of invalid and discriminatory dismissals (because of race, gender, religion or disability) and for very specific cases of unfair disciplinary dismissals, though courts will be requested to ascertain only the existence of alleged facts and not the proportionality between worker's misconduct and dismissal. These new arrangements will imply quite radical changes for Italy. To avoid unwarranted disruption, the new dismissal procedures will be applied only to new employment contracts ("grandfathering" existing rights).

20. According to the Jobs Act, workers unfairly dismissed for objective reasons will receive monetary compensation increasing with the tenure, instead of being reinstated. The monetary compensation will be equal to 2 monthly wages per year of service (a minimum amount equivalent to 4 months and a maximum amount equivalent to 24 monthly wages). By increasing predictability the Jobs Act lowers the effective costs of dismissal, even if judged to be unfair by courts, helping firms create more jobs. The amount of such compensation could be reconsidered, however; it is currently very high, considering the OECD average of 14 months at 20 years of tenure (see OECD, 2013b). 
21. The Jobs Act also introduces a new form of out-of-court procedure, according to which the employer can pay the worker an indemnity equal to 1 monthly wage per year of service (a minimum amount equivalent to 2 monthly wages and a maximum amount equivalent to 18 monthly wages). This compensation could be considered as similar in some respects to severance pay. The acceptance of this transaction prevents any further dispute by the worker, that is, appealing to courts for a dismissal to be unfair or not. Both parties have a strong incentive to settle the dispute through this procedure, since the sum paid is not subject to social contribution or fiscal taxation. The government is committed to monitor the developments on this new procedure and, if necessary, it should consider alternative measures to reduce uncertainty on court decision.

\section{Unemployment benefits and social assistance}

\section{Box 2. Unemployment and social benefit system in transition}

The 2012 reform overhauled the unemployment benefit system. The previous ordinary unemployment benefit will have been gradually replaced by the Assicurazione Sociale per l'Impiego (ASpl), integrated with one of the special benefits (IM, see below), by 2017. The eligibility condition for the ASpl remains unchanged, requiring two years of contributions, of which 52 weeks have been accumulated in the last 2 years. The so-called "mini-ASpl" is made available for those not qualifying for the ASpl, with a minimum contribution of 12 weeks in the last 52 .

ASpl (EUR 2725 million, 960000 beneficiaries in 2013) is paid to workers individually laid off in the private sector or collectively laid off but not eligible for other benefits who have paid contributions for at least 52 weeks during the two-year period prior to unemployment. The benefit is $75 \%$ of the average gross earnings received over the last 3 months for the first 6 months following unemployment, subject to a threshold (EUR 1180 as of 2013) above which this ratio is reduced. After 6 months, the benefit amount is reduced to $60 \%$. The benefit duration is 8 months (for those over 50 years old, it is 12 months).

Mini-ASpl (EUR 1447 million, 380000 beneficiaries in 2013) has the same amount payable as that for the full ASpl. The duration is limited to $50 \%$ of the contribution record for the past 12 months.

There are also special benefits which are provided in a sequential way to workers in specific sectors under certain circumstances. When added up, these benefits accounted for much more than the previous ordinary unemployment benefit.

Cassa Integrazione Ordinaria, CIG-O (EUR 1132 million, estimated 90000 beneficiaries in 2013), wage supplementation for short-time working scheme (thus not exactly an unemployment benefit), is usually paid for 13 weeks but it is possible to obtain some prorogation if the firm remains in a reduction of activity for a longer period. In any case, CIG-O cannot be paid for more than 12 months, whether consecutive or non-consecutive, over a period of 2 years. The replacement ratio is $80 \%$ of the previous salary subject to a monthly ceiling (EUR 1166 as of 2013). The beneficiaries are those who work in the firms where activities are reduced or suspended due to cyclical weakness or unforeseen events in the industry and construction sectors (where the social security contribution rate is higher by some $2 \%$ ).

Cassa Integrazione Straordinaria, CIG-S (EUR 1952 million, estimated 140000 beneficiaries in 2013) is normally paid for 12 up to 24 months. The beneficiaries are those who work in firms facing crisis and/or restructuring in the industry sector or other designated sectors. It is possible to obtain prorogation if restructuring lasts more than 24 months. In any case, CIG-S cannot be paid for more than 36 months over 5 years. The replacement ratio is $80 \%$ of the previous salary subject to the same monthly ceiling as CIG-O.

Indennità di Mobilità, IM (EUR 1951 million, 310000 beneficiaries in 2013) is provided in case of collective dismissals by firms eligible for benefits from the CIGs and in case of individual dismissal of workers already in CIG-S or under bankruptcy proceedings. The duration of mobility benefits depends on the age of the recipient and on the location of the job. For instance, workers under 40 years old are entitled to this benefit for 12 or 24 months, respectively according to whether they had worked in the Centre-North or the South. The benefit duration is extended up to 36 or 48 months respectively for workers over 50 years old. The benefit amount is $100 \%$ of CIG-S for the first 12 months and the reduced to $80 \%$ subject to the same monthly ceiling as CIG-O.

The OECD Benefits and Wages allows comparisons of the welfare benefits to those in and out of work as well as the taxes they are liable to pay. The series addresses in a systematic way, country by country, the complicated 
interactions of tax and benefit instruments. It includes analyses of net incomes in and out of work for different family types and labour market situations, presented in a format which facilitates cross-country comparisons.

In the OECD Tax Benefit model, the ordinary unemployment benefit is taken into account for Italy. The net replacement rate is close to the OECD average in the initial phase of unemployment, but it reaches zero after an unemployment spell of two years.

Figure 11. Income support for the long-term unemployed is very weak in Italy

Overall net replacement rates: net income while out of work in percentage of net income in work, 2011 $\%$

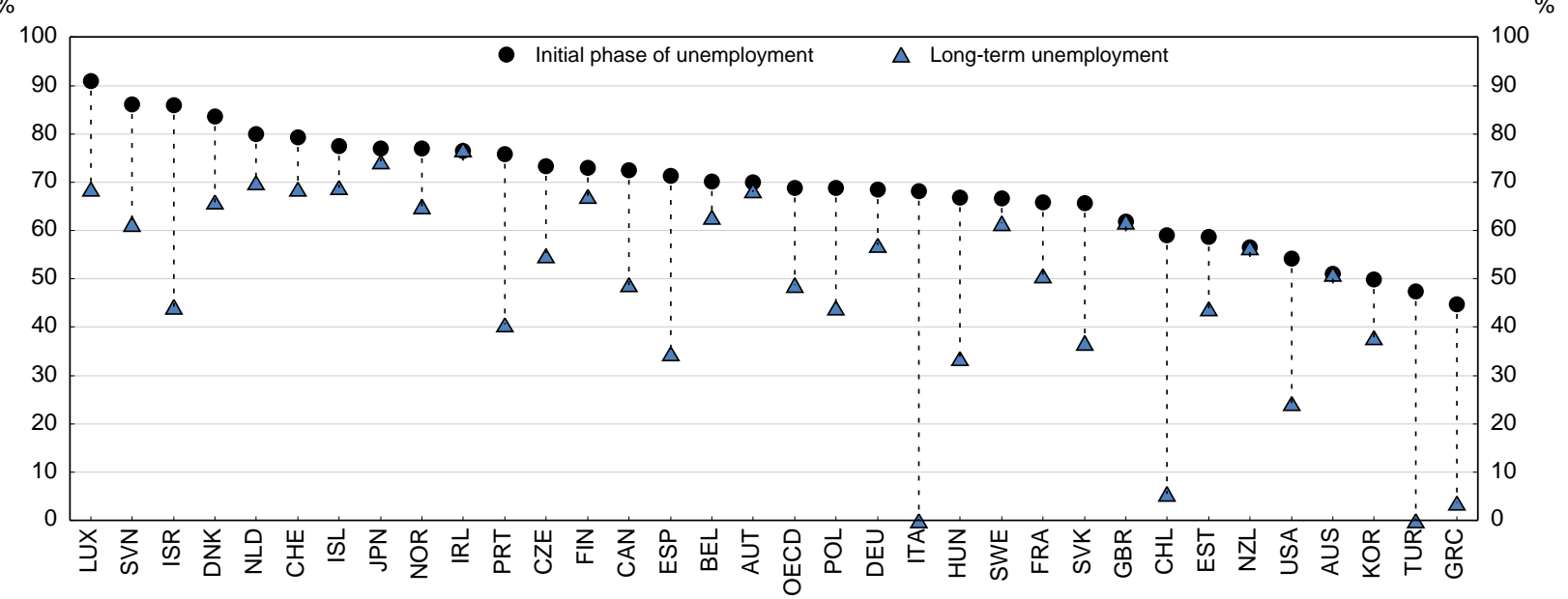

Note: "Initial period of unemployment" and "long-term unemployment" show the net replacement rate of the first month of benefit following any waiting period and of the 60th month of benefit receipt, respectively.

Source: OECD Society at a Glance (www.oecd.org/social/societyataglance.htm), Chapter 5, OECD Tax-Benefit Models (www.oecd.org/els/social/workincentives).

The problems with the unemployment benefit system

22. Unemployment benefits help to improve the labour market if well-designed. However, if too generous, especially in terms of income replacement, they may have pervasive effects on labour supply incentives. The replacement income offered by unemployment benefits improves the outside option of workers and raises the reservation wage above which workers generally accept to work. This generates upward pressure on the average wage and raises the unemployment rate (Pissarides, 2000). If unemployment benefits are generous only for those with permanent contracts, and not for new entrants with temporary contracts, then they generate wage premium for the former, though at a higher risk of job destruction for them, resulting in a higher unemployment rate in an economy as a whole (Boeri, 2011).

22. In Italy, the unemployment benefit system provides generous benefits for those with permanent contracts, while its coverage for non-regular workers has been very low (Box 2). The standard unemployment benefit (UB) had a replacement rate close to the OECD average, but with a relatively short duration. At the same time, additional benefits (notably Cassa Integrazione Ordinaria, CIG-O, Cassa Integrazione Straordinaria, CIG-S, Indennità di Mobilità, IM, see Box 2) have been provided for workers in specific sectors under certain circumstances. These benefits are generous in terms of both the replacement rate and duration.

23. The 2012 reform streamlined different kinds of benefits while introducing eligibility for shortterm workers. The reform first introduced a new benefit scheme Assicurazione Sociale per l'Impiego (ASpI) which integrates the standard unemployment benefit (UB) and one of the special benefits (IM). The 
ASpI will be gradually phasing in by 2017. The replacement ratio under ASpI is higher than under UB but lower than special benefits including IM. The reform also introduced the so-called "mini-ASpI" which covers those with a minimum contribution record of 13 weeks out of the last 52 weeks, thus extending de facto the eligibility to many temporary workers. These measures extended the population of potential beneficiaries by some 1.5 million, according to estimates by INPS, the Italian Social Security Institute.

\section{The Jobs Act integrates the benefit system}

24. The Jobs Act further extends the coverage of unemployment benefits, consistent with easing EPL, thus bringing Italy closer to a "flexicurity" approach. The Jobs Act integrates ASpI and mini-ASpI, thus harmonising their different eligibility requirements and durations. The "new ASpI" will be paid for a duration reflecting the number of weeks of contributions over a longer reference period and it will be extended - on an experimental basis - at around 350000 project workers (currently excluded from the protection).

25. The Jobs Act will also more closely associate the provision of unemployment benefits with individual efforts made to return to work. The implementation of such "mutual obligation" approach depends on detailed criteria, such as the types of jobs that an unemployed person must accept, the degree of geographical mobility that is required and requirements concerning job referrals and active job search (OECD, 2013b). In addition, this may include the obligation to enter into employment and training programmes enforced by benefit sanctions (OECD, 2013b).

26. The Jobs Act will reform the social assistance provided to vulnerable people attached to the labour market. In Italy, non-contributory benefits (on account solely of low income) have not existed. The government introduced a new pilot programme, Sostegno per l'Inclusione Attiva (SIA), to support the population in poverty. SIA targets households with children and a working-age member out of employment for at least three years. It aims at closing the gap between the household income and the absolute poverty level. In return, beneficiaries must commit to an activation plan. The Jobs Act plans to extend the coverage of SIA, but it will fall short of financing all the population in poverty. SIA should be prioritised so that it extends its coverage as much as public finance would allow, while avoiding perverse effects on labour incentives.

\section{Active labour market policies (ALMPs)}

\section{Box 3. Structure of authorities/institutions and ALMPs}

In Italy, public employment service (PES) is organised at different levels: central government, 19 regions and 2 autonomous provinces. The Ministry of Labour and Social Policies designs labour market policies in cooperation with the regions and autonomous provinces and coordinates PES actions at local levels. It is regions and autonomous provinces who are responsible for designing and implementing regional labour market policies. This structure results in different organisational models which can be found at local level.

The following are services typically provided at local level in Italy: registration and information services; career guidance; collection, submission and promotion of job vacancies; profiling; support for self-employment and entrepreneurship; support to the employers; assistance to the disabled and disadvantaged groups. 


\section{Figure 12. ALMP spending is relatively low and concentrated on some categories}
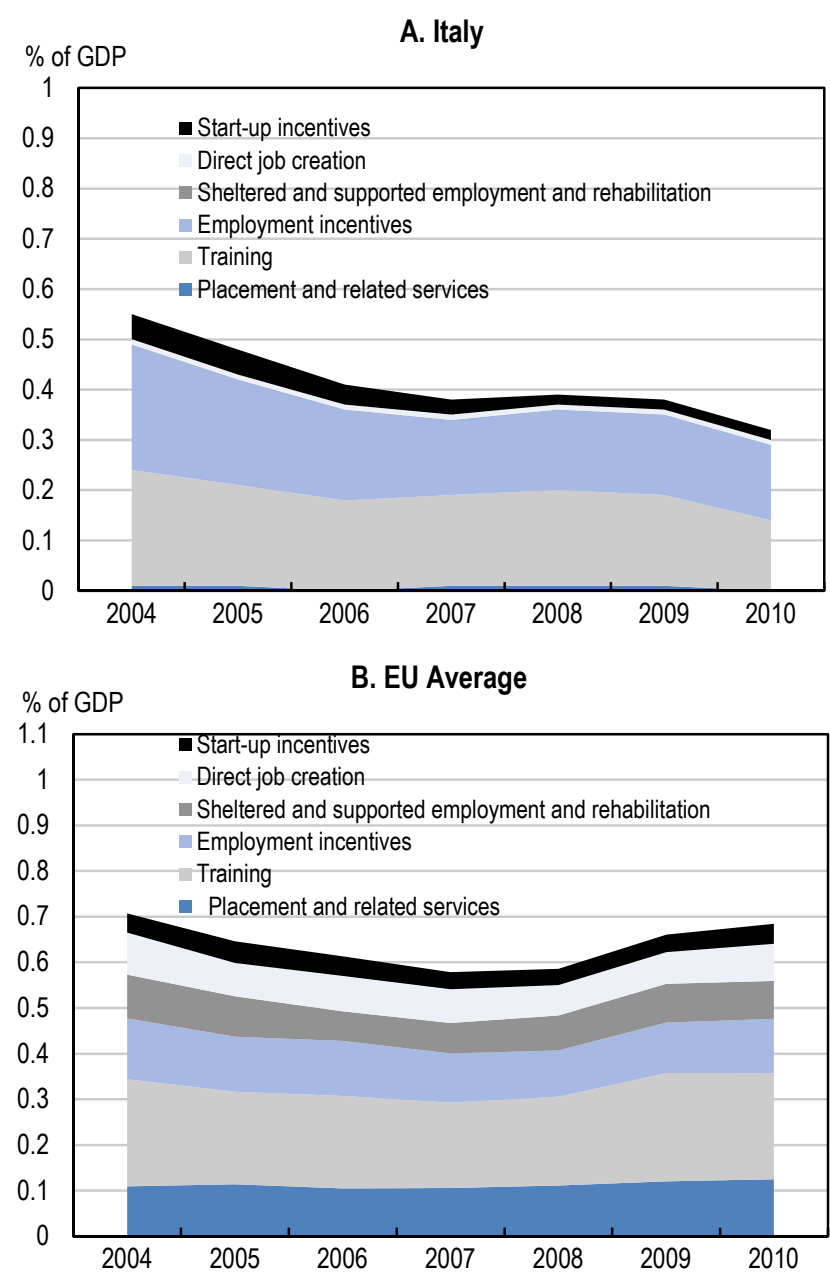

Source: OECD database on labour market programmes.

\section{EU Youth Guarantee}

The EU Youth Guarantee scheme has been in force since mid-2014. The Youth Guarantee programme provides those who are 15-29 years old an opportunity of job orientation and job training within four months after leaving school or being laid off.

This programme offers a range of activities to young people such as: guidance, education and training courses including self-employment interventions and measures to help young people in opening up new entrepreneurship activities, incentives for the enterprises to employ young people or for making available apprenticeship or traineeship places. These measures are expected to facilitate school-to-work transition.

At the end of 2014, half of the resources available (EUR 1.5 billion) have been allocated for activation measures and employment incentives by local authorities responsible for the implementation of the programme; 126670 NEETs have been profiled and taken in charge by PES for tailored services provision.

In Italy, the implementation of this programme is considered to be an opportunity to more permanently improve the activation system, which will be eventually extended to other categories of people. An integrated information system has been established monitoring beneficiaries of this programme, and such an information system will be useful to identify relevant polices for different job seekers. 


\section{What can be expected from ALMPs?}

27. ALMPs aim to strengthen matching efficiency in the labour market, reducing frictions in the vacancy filling process by assisting job seekers. ALMPs act on recruitment costs (through job counselling, placement services, etc.) as well as on after-tax wages (making work pay). Such measures encourage firms to open new vacancies and unemployed workers to accept a job. Thus, both parties are better off from a job matching, the profit of which is shared depending on their bargaining power (Boeri, 2011). ALMPs are targeted to new job matches by definition and they are opportune when the new standard contract imposes some disadvantage on newly hired workers.

28. In Italy, ALMPs have been under-developed and their implementation has been dispersed across regions. The budget allocated to ALMPs has been much lower than the EU average (Figure 12). Local authorities manage the implementation and design of ALMPs. They take into account regional-specific economic and social situations, thus possibly pursuing different efficiency goals. Provision of social benefits, on the other hand, has been managed at the central level by INPS with virtually no direct link between passive and active policies.

29. The previous government began strengthening ALMPs in 2013 while designing the national plan for the EU Youth Guarantee programme. That government launched a new Struttura di missione in the Ministry of Labour, to coordinate and promote active policies: collecting data on public employment services (PESs); defining national guidelines for ALMPs; assessing PES performances. It also took measures to strengthen the role for PESs, in particular their capacity to provide career orientation services. The national Youth Guarantee scheme planned by the previous government has been in place since May 2014 (Box 3).

\section{The Jobs Act aims at efficient implementation of ALMPS}

30. The Jobs Act aims to strengthen effective implementation of ALMPs by creating Agenzia Nazionale per l'Impiego, the National Employment Agency. The Agency will be responsible for assuring an efficient conditionality approach for provision of unemployment benefits. This is an essential point, but its enforcement may be difficult: a conditionality approach was foreseen by the 2003 law but has never really been enforced because of difficulties in coordinating the different institutions involved. The institutional reform this time would hopefully overcome such difficulties, since the constitutional reform attributes ALMPs to the exclusive competence of the central government avoiding fragmentation and assuring a coherent framework. However, the details on conditionality are unclear at this stage and should be clarified.

31. The Agency, which will be also responsible for coordinating ALMPs across regions, should identify the appropriate measures for different job seekers and in different regions (Box 3 and Jin et al., 2015). In general, profiling is necessary to determine who is job-ready and who should be involved in more comprehensive programmes. Those who are job-ready need to quickly return to work before skills are lost. Most of displaced workers find jobs that use similar skills to their pre-displacement jobs, even if they move to a new occupation or industry (OECD, 2013b). In such cases, measures facilitating job matching such as career orientation and placement services seem to suffice. Job training programmes are costly and should be targeted to some identified groups, such as the long-term unemployed, lower educated people, and job seekers in southern regions. The government has installed an integrated information system monitoring beneficiaries of ALMPs and this system will enable policy makers to identify relevant policies in the future. 
ECO/WKP(2015)84

\section{Wage setting system}

32. Wage setting is a decisive factor which contributes to both structural performance and labour market resilience. Flexible wage setting is important in achieving low structural unemployment rates and in mitigating the direct impact of shocks on employment by facilitating adjustments (OECD, 2014b). In general, the wage bargaining system has an essential role in wage setting, especially when there is no legal minimum wage, as in Italy.

What characterises Italy's wage bargaining system?

33. In Italy, Contratto collettivo nazionale di lavoro (CCNL), plays a determinant role in wage formation. CCNL is an industry agreement reached between business associations and labour unions in each industry. This agreement is applied uniformly within the same sector across the country, through the functional equivalent to administrative extension: the terms and conditions of collective contracts are extended to the total workforce, whether unionised or not, since a clause in the Constitution guarantees a binding character of collective contracts (OECD, 2004). This system of collective bargaining has contributed to reducing labour conflicts.

34. However, the wage bargaining system in Italy has many characteristics which have been thought as less efficient in terms of wage setting. Bargaining at industry level is less efficient than centralised bargaining, which takes into account macroeconomic effects of wage settlement, and firm-level bargaining, where unions exercise relatively little monopoly power (Calmfors and Driffill, 1988). Higher bargaining coverage through administrative extension is generally found to be performing worse (for e.g. higher unemployment, see Aidt and Tzannatos, 2008). Among recent studies, Bassanini and Duval (2009) empirically confirm the negative effects of this institutional setting.

35. In Italy, wages have not been reactive enough to macroeconomic developments. CCNL basically links contractual wages to the CPI forecast (excluding energy) over the following three years. Once committed, adjustments can be made only at the next round of negotiation, thus three years later. Sluggish wage adjustment is reflected in the evolution of contractual wages: nationally negotiated wages have increased on average by $2.7 \%$ per year in the industry sector excluding construction and by $2.3 \%$ in the private service sector, both in the 2001-07 period and in the 2008-13 period, according to Confindustria.

\section{What are other factors influencing wage setting?}

36. Wage setting is also interrelated with other labour market institutions such as EPL and its dualism. For Italy, Leonardi and Pica (2013) find that EPL affects the wages of those with long job tenures, but they found no such impact on entry wages, reflecting the duality in the labour market. According to OECD estimates, the wage penalty for temporary workers is $7-10 \%$ in full-time equivalence all else equal (i.e. controlled by age, education, regions, etc., see Figure 13). 
Figure 13. Labour market institutions affect wages for different categories

Estimated wage difference between full-time non-regular and permanent employees

$\%$

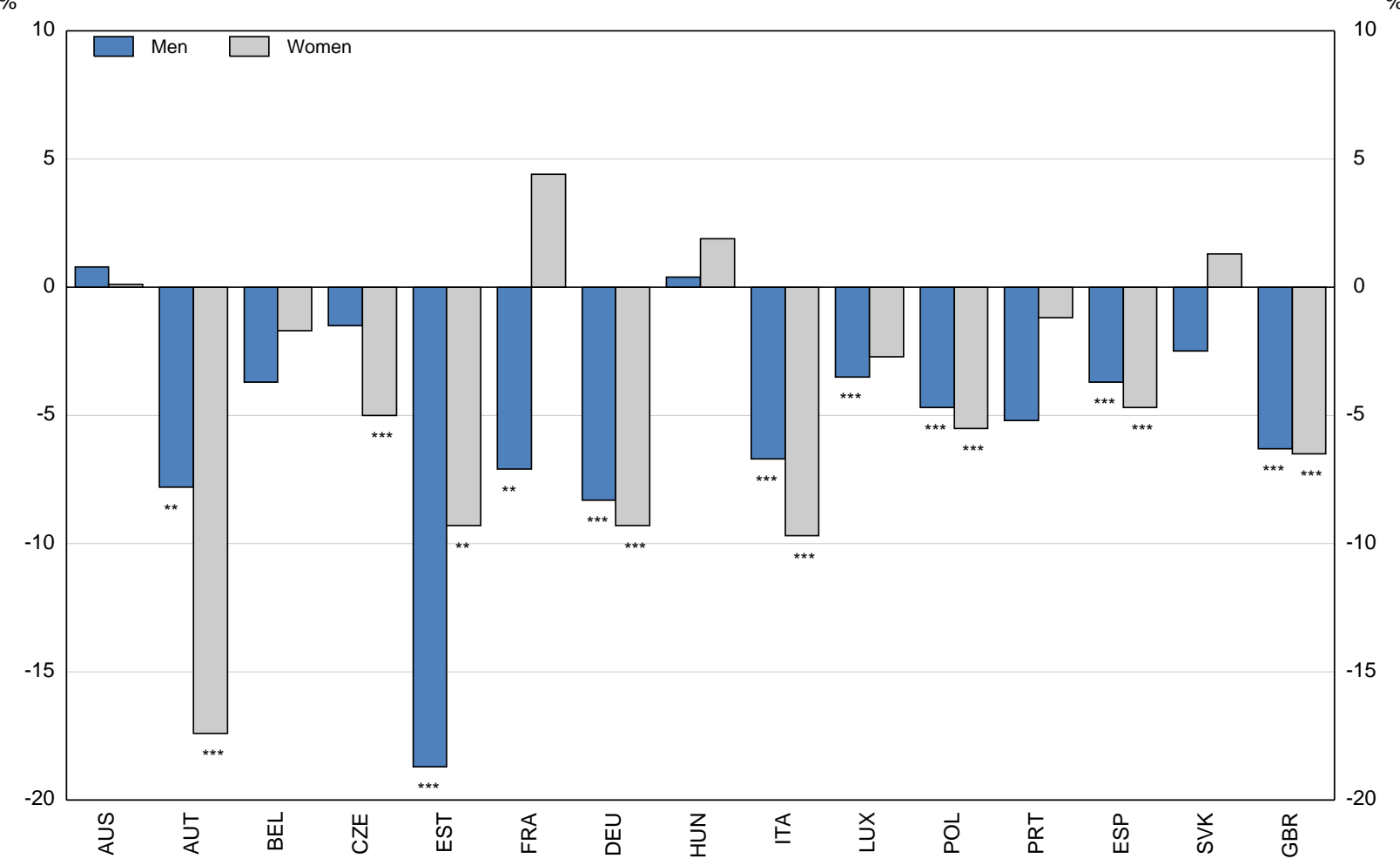

Note: The figure reports the estimated average difference in hourly wages between non-regular and permanent employees working full-time, expressed in percentage of the wage of the latter. Estimates are obtained through a fixed-effect linear model of log hourly wages controlling also for dummies for five age classes, three education levels, married status, children below 13 years and bad health conditions as well as region and time dummies. Casual workers are classified as non-regular employees.

***, **: significant at the $1 \%$ and $5 \%$ level, respectively.

Source: OECD Employment Outlook 2014, Chapter 4, OECD Publishing, Paris, http://dx.doi.org/10.1787/empl_outlook-2014-en, Chapter 4.

37. Wage adjustment against cyclical weakness has been borne disproportionately by new entrants. OECD (2014b) finds that in EU countries an increase of one percentage point in the unemployment rate generates a decline in earnings of $-0.5 \%$ and $-3.0 \%$ for job stayers and job movers, respectively (Figure 14). This suggests that adjustments have been largely made at the margin both internally (labour costs) and externally (employment quantity). These findings indicate the need to reform employment protection legislation and wage setting process in a coordinated way. 
ECO/WKP(2015)84

Figure 14. Wages are more elastic for new hires than incumbent workers

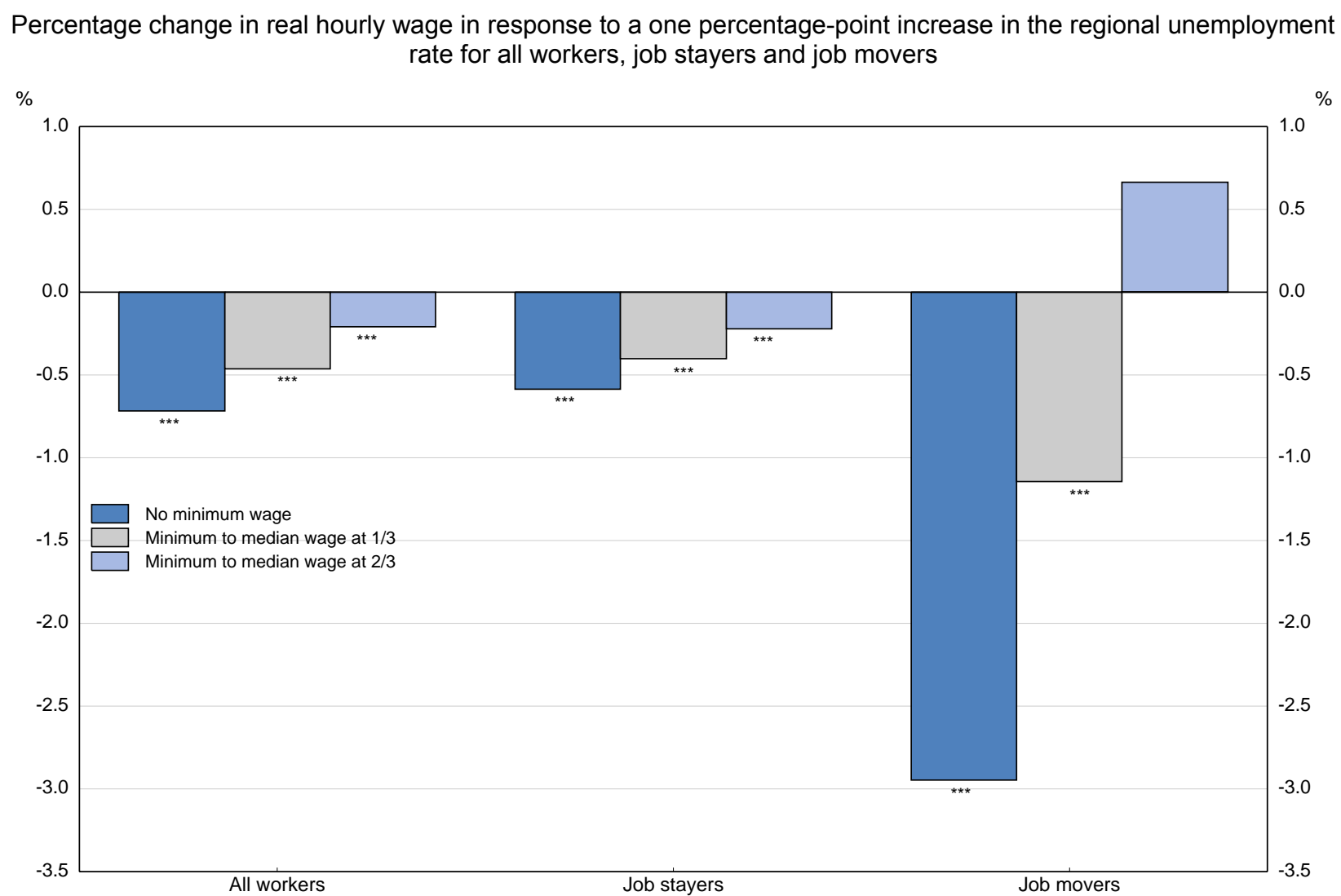

Note: ${ }^{* * *},{ }^{* *},{ }^{*}$ : statistically significant at $1 \%, 5 \%$ and $10 \%$ levels, respectively.

1. OECD estimates using worker-level panel data for selected European countries during the period 2005-10. The estimates are based on the European Union Statistics on Income and Living Conditions (EU-SILC) and national labour force surveys for France and the United Kingdom. Estimates control for person fixed effects.

Source: OECD Employment Outlook 2014, Chapter 2, OECD Publishing, Paris, http://dx.doi.org/10.1787/empl_outlook-2014-en, Chapter 2

How the wage bargaining system can be improved?

38. The wage setting mechanism should be made more flexible, so as to take into account firmspecific conditions such as productivity. The three-party pacts in 2011 and 2012 by the government, business associations, and trade unions increased, in theory, the role of firm-level negotiations. However, their role is still very limited (subject to the fields specified in collective agreements) and generally allowed for incremental adjustments, linked to productivity, to collectively agreed terms. Consequently, firm-level negotiations currently remain of little importance. Alternatively, wage flexibility would be made greater if firms deciding to opt out of collective bargaining were allowed to strike a deal with trade unions representing only a majority of employees, and not all trade unions as currently is the case. In Spain, provision for firms to opt out fully from national contracts to achieve lower costs is credited with having helped competitiveness (OECD, 2014c).

39. Such an arrangement in the wage bargaining system would also alleviate regional disparities in labour outcomes and economic performance. Insufficient wage adjustment at the regional level may be partly responsible for the persistence of employment disparities. In general, regional disparities in 
employment are positively correlated with disparities in productivity levels (e.g. Sestito, 2004). In intermediary wage-bargaining systems, those relying mostly on industry-level bargaining, outcomes are influenced mainly by the economic conditions prevailing in the leading sectors and regions. This may create a gap between wages and productivity in lagging regions. Such a gap would reduce the incentives for investment in those regions. Decentralising wage-setting could thus help in reducing regional employment disparities, by stimulating job creations in lagging regions (OECD, 2006).

What will be changed in introducing minimum wage?

40. The Jobs Act will introduce a legal minimum wage on an experimental basis, an institutional feature that has not existed so far in Italy. A minimum wage, if not carefully designed, tends to induce wage rigidity, in turn resulting in higher unemployment. On the other hand, it has some balancing effects, limiting large wage penalties for those with less bargaining power: Figure 14 shows that the extent of disproportionate wage adjustments between incumbents and new entrants is reduced when a minimum wage is in place.

41. Though not foreseen in the enabling law, introducing a legal minimum wage could be an opportunity to set an adequate floor on wages across different regions. The optimum wage level is almost certainly different across regions, given the productivity differential. Such region-specific minimum wage rates exist in other OECD countries, such as the United States, Canada and Japan where minimum wage rates are set taking account of different levels of productivity across regions. It is possible to maintain the system without reducing potential employment opportunities, as is the case in Japan (Higuchi, 2013). Such a differentiated minimum wage across regions should be considered in Italy given different productivity levels (see Figure 4). The differentiated minimum wage can be also justified by different costs of living: in lagging regions, lower prices (especially housing) sometimes more than offset lower wages in terms of purchasing power (Boeri et al., 2014).

\section{More and better quality jobs in a dynamic and inclusive economy}

42. A set of well-designed institutions, not only labour market policies but also the education system and product market regulation, would encourage higher labour force participation and produce more and better quality jobs in a more skill-intensive economy. Such institutions would bring higher sustainable growth and inclusiveness, thus improving people's well-being.

\section{Labour force participation}

43. A further increase in labour force participation shifts up the trajectory of potential output. This is especially important for Italy, since the working age population will soon begin to diminish due to demographic factors, while immigration is expected to have very limited influence over the long run according to Eurostat's estimates. Overall, downward pressure in the labour force participation rate will become stronger due to the aging society. The current policy stance linking the average duration of active life to life expectancy will only moderately offset the negative impacts from diminishing working age population. Instead, the policy should aim at further reducing the gap between the effective working life in Italy and that in other countries, as potential gains are very large for Italy (OECD, 2014d).

\section{Institutions can distort incentives to work}

44. Low labour force participation can result from disincentives to work due to the fiscal system and labour market institution. These include high and/or ill-targeted labour taxation and implicit tax on continuing work which has encouraged de facto early retirement. 
45. After the 2011 pension reform, all age requirements and the contribution requirements for a full pension will be increased in line with life expectancy. In order to obtain a full pension, the required contribution period is 42 years and 3 months for men and 41 years and 3 months for women as of 2014 . Those who are under the statutory retirement age, up to a maximum of three years, can also retire earlier, with a reduced pension, as long as they have a record of more than 20 years of contributions (and if their pension is higher than a certain threshold). The reform has restrained exits from the labour market and the labour force participation rate among older people has visibly increased since then (from $46.3 \%$ to $56.7 \%$ in the five years to 2013). 
Figure 15. Tax wedge is high in Italy especially among low-income earners
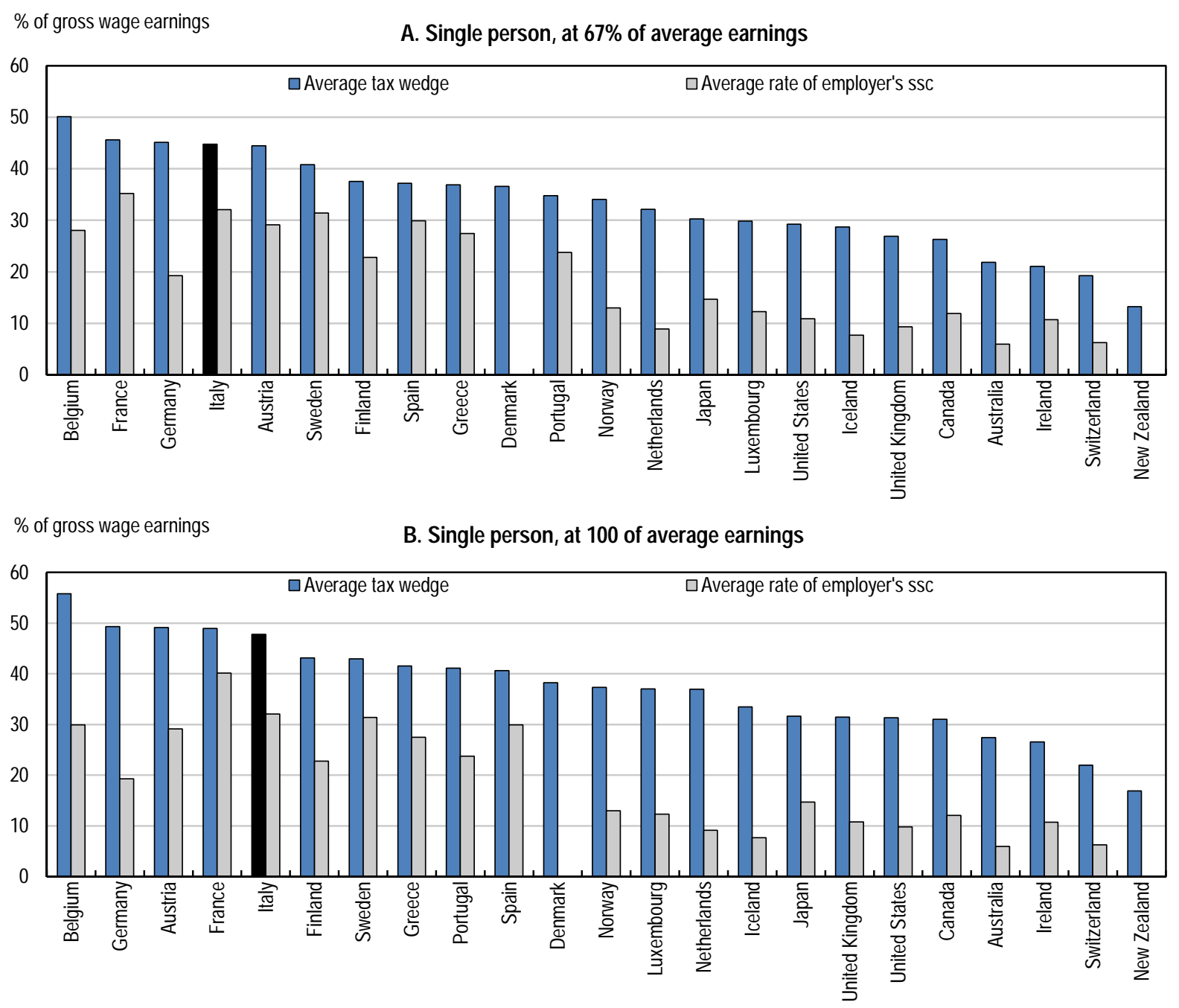

C. Two-earner married couple, one at $100 \%$ of average earnings, the other at $67 \%$, two children

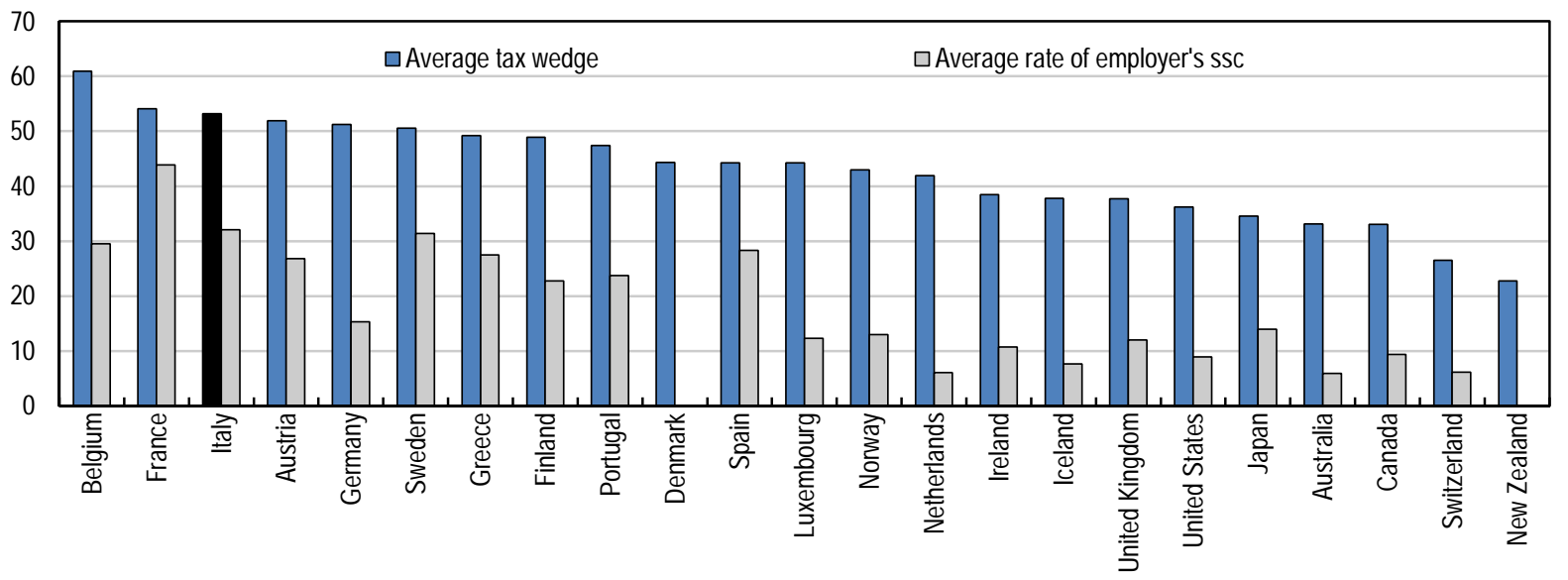

Source: OECD Taxing Wages, OECD Tax-Benefit model. 
46. The tax wedge is generally high in Italy, and especially so among low-income earners. The high overall tax burden is the mixture of high taxation on labour income and of even higher social security contribution by the employer (Figure 15). Such high taxation induces lower labour demand and/or disincentives to work. An across-the-board tax reduction would be expensive and such a tax cut should be targeted to low-income workers, given the relatively high taxation on them compared with other OECD countries. If a tax cut is targeted to certain income levels, then the authorities should carefully avoid trapping workers to the same income levels (i.e. avoiding high and abrupt marginal tax rates).

47. In 2014, the government introduced a EUR 10 billion overall tax reduction benefitting lowincome dependent workers with an annual labour income of less than EUR 26000 . A lump sum tax reduction equivalent to EUR 80 per month is paid on incomes up to EUR 24 000, and gradually phased out as labour income attains EUR 26000 . This tax reduction is estimated to benefit about 10 million employees (those with a take-home pay of less than EUR 1500 per month). The government has financed this measure broadly in a finance-neutral way. This measure is extended to the year 2015 and will become permanent.

48. The government will temporarily remove employers' social security contributions for new hires on permanent contracts during the period 2015-17, for low income workers earning up to EUR 25000. Along with the cut in income tax of a fixed amount per month up to a certain income limit introduced in 2014, this should stimulate job creations with the new standard contract: including the impact of the income tax cut, the tax wedge for the same employee falls from $46 \%$ in 2013 to $21 \%$. This measure is expected to be extended in the following years. The government may consider avoiding high marginal tax rates: firms will be penalised in increasing wages above EUR 25000 by the standard rate of social security contribution of $32.08 \%$.

\section{Reconciling work/family life}

49. Low female labour force participation is not necessarily a result of unconstrained choice. It is influenced by responsibility for caring for children or older family members, and also possibly by the tax system for families. The female labour force participation rate has been increasing steadily, due to the cohort effect reflecting higher educational attainment of the current generation, and is expected to continue to do so. However, its level still remains well below the OECD average. If the gender gap in labour force participation were to be halved by 2030 this is projected to lead to an annual increase in growth of GDP per capita of 0.5 percentage points - about twice the OECD average (Thévenon et al., 2013; see OECD, 2012, and OECD et al., 2014, for recent OECD initiatives to tackle the gender gap).

50. The government plans to encourage female labour force participation by strengthening financial incentives to work for women. The average tax wedge for a two-earner married couple (with or without children) is generally very high in Italy (Figure 15). For instance, for a couple with two children, one is earning $100 \%$ of the average earnings and the other at $67 \%$ - typical model case -, the tax wedge is $42.9 \%$ which is among the highest in the OECD countries. The government introduces a tax credit for low- and medium-income families with children while reshaping tax deductions for a dependent spouse. This enhances their work incentives.

51. In Italy, fewer children below three years of age are enrolled in formal childcare than the OECD average (24\% against $33 \%$ ). At $2 \%$ of GDP, public spending on family benefits is below average in Italy and most of it concerns cash benefits and/or tax measures. Public spending on family services (including on early education and childcare for little children) is also low in international comparison. Access criteria to childcare facilities are rigid, but these are also related to capacity constraints. In this regard, the integration of access criteria and tariffs between public and private childcare services should help optimise access, as should an integration of employer-based childcare services with the public-private system. The 
government introduces a "baby bonus", a yearly cheque of EUR 960 for each child born or adopted from 2015 to 2017 for medium- to low- income families. In view of the range of benefits such support has it may be advisable to use the available funds for additional investment in childcare facilities.

52. In addition to childcare supports, flexible working arrangements such as flexibility in working hours as well as teleworking can help parents to reconcile work and care responsibilities. Such arrangements are usually decided by collective bargaining. Social partners may be encouraged to prioritise a change in this area. The government could also consider legislation to support access to flexible workplace measures for workers with very young children, as exist in different OECD countries (OECD, 2011b).

\section{Education and skills}

53. Human capital accumulation is in itself favourable for labour augmenting productivity (OECD, 2014d). Demand for highly educated workers will rise as the economy becomes more skill-intensive. This will raise in turn demand for tertiary education, driven by high economic returns and better employment prospects for graduates. Simultaneously, an increase in the supply of highly educated workers would diminish wage premiums, alleviating the upward trend in inequality. Indeed, more and the right kinds of education and skills are needed to keep up with the changing industrial structure and skill-biased technological progress.

\section{Educational attainment should be increased}

54. The average level of educational attainment is currently low in Italy (Figure 16), which is related to worse labour outcomes for youth. Low educational attainment is largely explained by early school leaving. Dropout is concentrated in the first cycle of secondary school as well as in technical and professional institutes. Such a phenomenon is more pronounced in socio-economically difficult regions (OECD, 2009). Those who dropped out without a recognisable diploma tend to compound difficulties in the labour market insertion and easily end up becoming Not in Employment, Education or Training (NEETs) (OECD, 2010). The NEET rate among youth is around 20\%, the highest among European countries. Standard ALMPs are known to be inefficient for this category of people and preventive measures (such as outreaching students whose risk of dropping out is high) are found to be effective (OECD, 2010). 
Figure 16. Educational attainment is low

Percentage of population aged 25-34 and 45-54. 2011

A. Upper secondary education

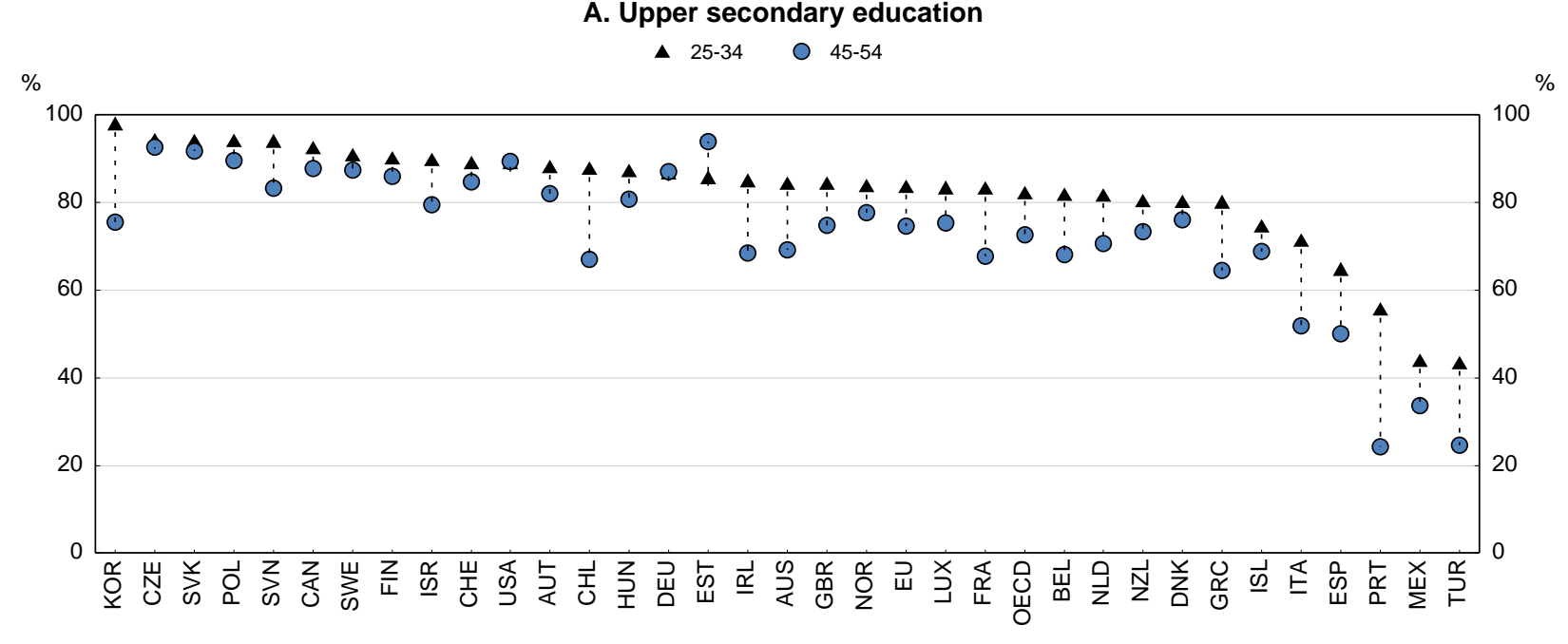

B. Tertiary education

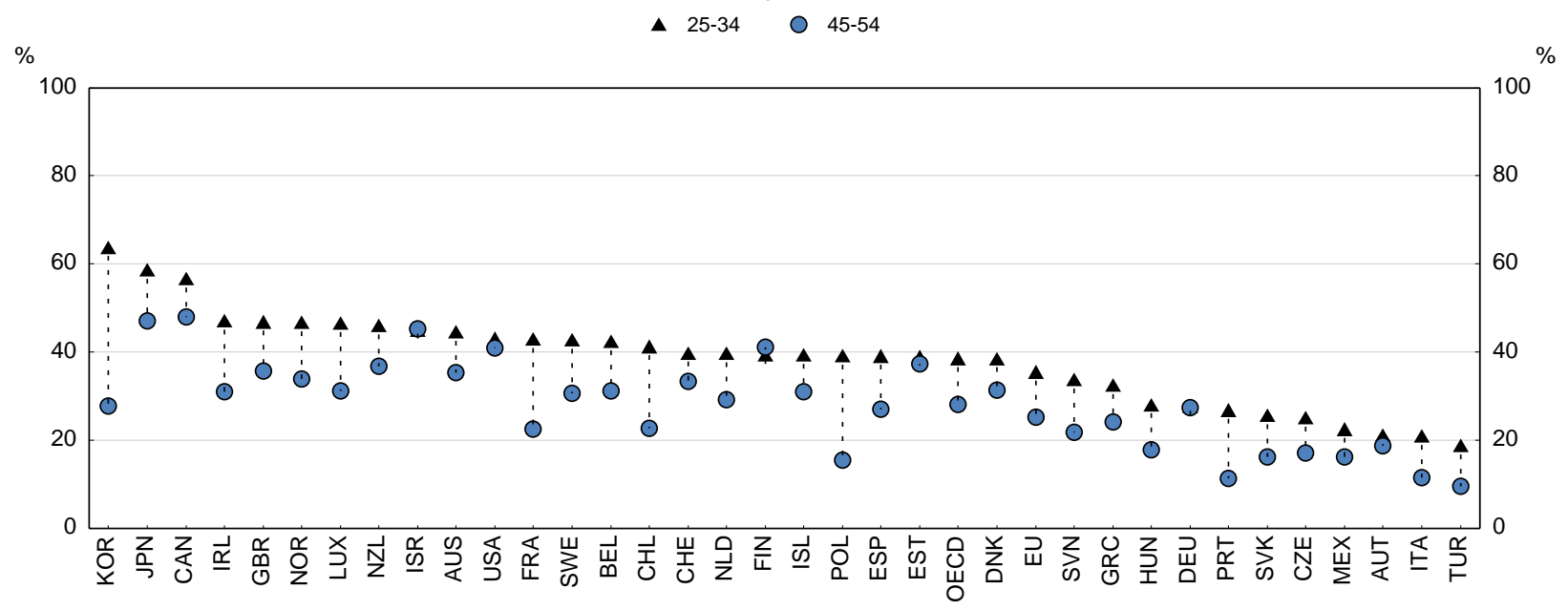

Source: OECD (2013), Education at a Glance 2013: OECD Indicators, OECD Publishing, Paris.

\section{How to increase returns from education?}

55. Returns to education are lower in Italy than other OECD countries (Figure 17), which is attributed both to the education system and to the labour market. Educational attainment and specific skills related to field of study have a strong effect on wages, which is especially important for youth (OECD, 2014b). Figure 17 shows that returns to education are among the lowest in Italy and they are even lower once skills are controlled, which essentially singles out additional returns generated by specific skills related to field of study (once skills acquired through education are directly taken into account). This is another illustration of inadequate matching between field of study and occupational requirements in Italy. 


\section{Figure 17. Returns from education are low}

The return to one additional year of education, with and without controlling for other skill areas (youth 16-29)

Percentage increase in hourly wages associated with one extra year of education

$\%$

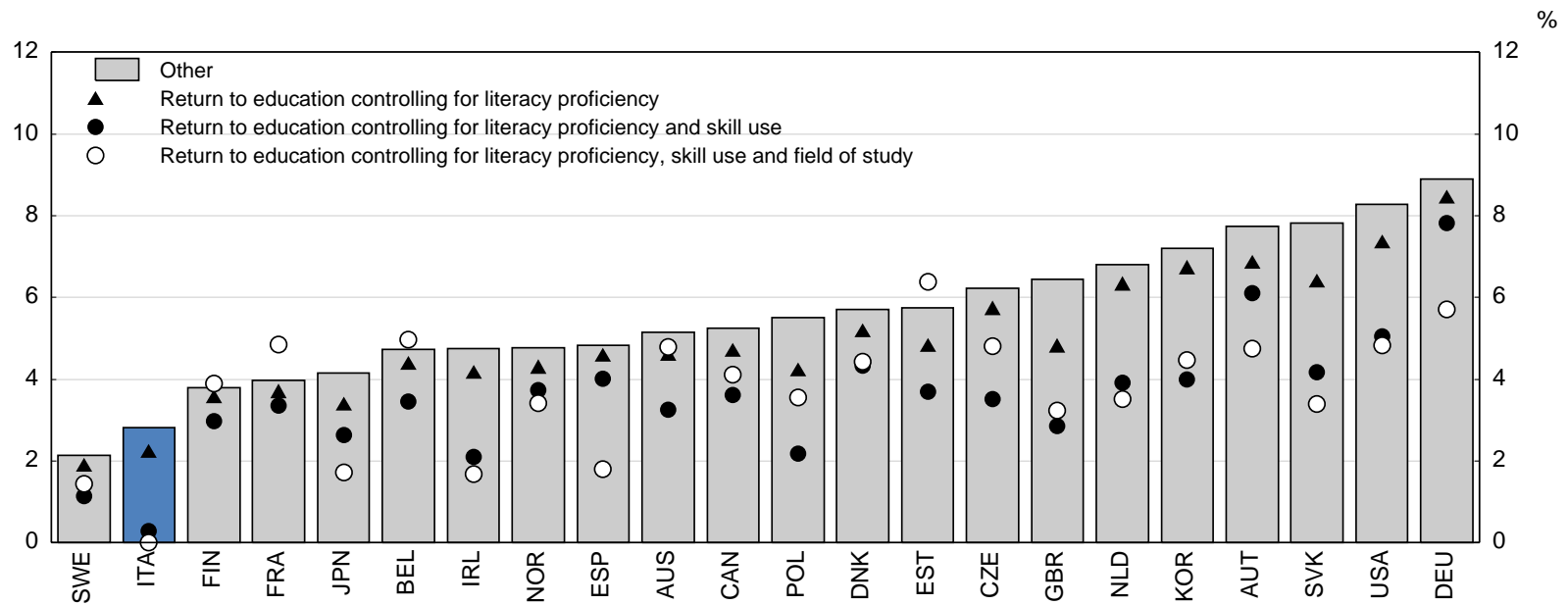

Note: Results obtained from a linear OLS regression (run by country and correcting for measurement error and sampling design) of log hourly wages on years of education, gender, marital status, migration status, language spoken at home, experience and its square. Other controls are added in separate steps: literacy proficiency is added in a second step; controls for the use of reading, numeracy, writing, ICT, problem-solving, task discretion, learning, influencing, co-operation, self-organisation, dexterity and physical skills at work are included in a third step; and dummies for field of study are added in the final step.

Source: OECD Employment Outlook 2014, Chapter 5, OECD Publishing, Paris, http://dx.doi.org/10.1787/empl_outlook-2014-en.

56. The evidence on job mismatch suggests a need for better orientation of students in their field of study. ISFOL, a public body for vocational training, studies the total occupational needs over a five-year horizon, forecast for 28 sectors and 129 occupations at national level and at regional level. In addition, employment supply and demand are estimated for major fields of education both for secondary and tertiary graduates. Such information should be systematically used in the guidance system which the Italian government has been developing: for example, an interactive dashboard involving companies, associations and industry representatives, developed within the context of the Youth Guarantee scheme.

\section{Industry needs should be taken into account}

57. A different kind of misalignment exists between the education system and labour market demand, resulting from lack of practical aspects in the workplace. This holds true even for vocational education and training (VET), which have a strong academic focus but a poor work-related one. OECD evidence shows that professional experience during school also helps youth in their labour market insertion, as it explains some $5 \%$ of the variation in hourly wages among youth (OECD, 2014b). In Italy a system called Alternanza Scuola-Lavoro, through which students alternate between school and learning at the workplace, has existed since the mid-2000s. This remains underdeveloped: only $9 \%$ of students used this programme (a majority in vocational or technical schools), while less than $1 \%$ of firms hosted such students. In addition, a number of employment contracts related to apprenticeship exist, such as Apprendistato professionalizzante. These contracts are designed to promote the labour market insertion of youth through the acquisition of specific skills, while allowing firms to hire young people at low labour costs. Currently two out of three apprenticeship contracts are related to formal education. However, the link between curriculum in formal education and qualification acquired through such apprenticeship contracts should be better formalised through a national standard: qualification acquired in one region is not recognised in 
other regions. An Agreement was reached in late 2014 to establish a national standard for qualification to overcome this problem.

58. Vocational education and training should be provided in a coordinated way with industry needs. Istruzione tecnica superiore (high technical institute, ITS), a new post-secondary VET programme, involves employers actively from designing to management of courses and workplace learning is mandatory for students. Poli Tecnici Professionali (technical and vocational hub, PTP), a recent initiative at regional level, aims at linking education and industry needs, creating networks between technical colleges, vocational schools and industries. Such a cooperative approach should lead to higher technical specialisation which is effectively matched by demand for highly-skilled workers. These initiatives could be a preferred approach to promote workplace learning or VET in general, but the number of such cases is currently very limited.

\section{Product market/innovation}

59. Competition and innovations are key to sustainable economic growth, changing the course of labour augmenting productivity. Productivity growth can be enhanced by increasing competition, through encouraging entry of new firms embodying quality-improving innovations and by strengthening incumbent firms' incentives to adopt leading technologies. Also, increasing the quality of management and private R\&D will enable the economy to reap more benefits from new technologies, with additional productivity gains (OECD, 2014d). Product market competition can also be good for jobs by encouraging the creation of new companies and expansion of existing ones that can take advantage of new markets, products or processes.

\section{Better resource allocation through competition}

60. The product market does not seem to function in a competitive way, given the limited number of start-ups. The percentage of start-ups in all businesses has been low and decreasing (Figure 18). For the relatively limited number of start-ups, prospects for them to grow over time are also limited (Figure 19). This is unfortunate since these start-ups contribute largely to net job creation, as in other OECD countries: these start-ups had just over $15 \%$ of total employment in stock, but they accounted for over $40 \%$ of contribution to job creation each year over the period 2001-11 (Criscuolo et al., 2014). 
Figure 18. Number of start-ups is limited and declining

The share of start-ups among all firms

$\%$

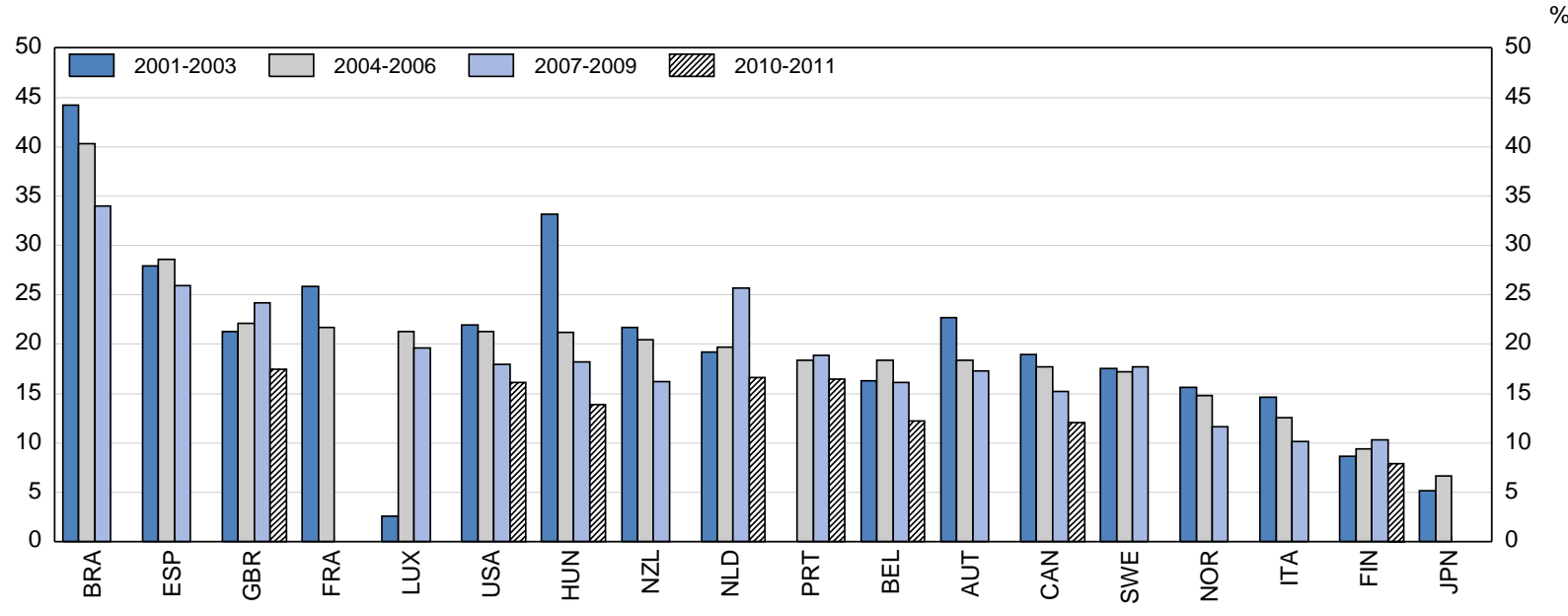

Note: The graph reports start-up rates (defined as the fraction of start-ups among all firms) by countries, averaged across the indicated three-year periods. Start-up firms are those firms which are from 0 to 2 years old. The period covered is $2001-2011$ for Belgium, Canada, Finland, Hungary, the Netherlands, the United Kingdom and the United States; 2001-2010 for Austria, Brazil, Italy, Luxembourg, Norway, Spain and Sweden; 2001-2009 for Japan and New Zealand; 2001-2007 for France; and 2006-2011 for Portugal. Sectors covered are: manufacturing, construction, and non-financial business services. Owing to methodological differences, figures may deviate from officially published national statistics. For Japan data are at the establishment level, for other countries at the firm level. Data for Canada refer only to organic employment changes and abstract from merger and acquisition activity.

OECD calculations based on firm level data from the ORBIS-Patstat Database for the non-farm business sector. See Andrews, Criscuolo and Menon (2014).

Source: Criscuolo, Gal and Menon (2014), "The Dynamics of Employment Growth: New Evidence from 18 Countries”, OECD Science, Technology and Industry Policy Papers No.14. 
ECO/WKP(2015)84

Figure 19. Many start-ups do not grow much

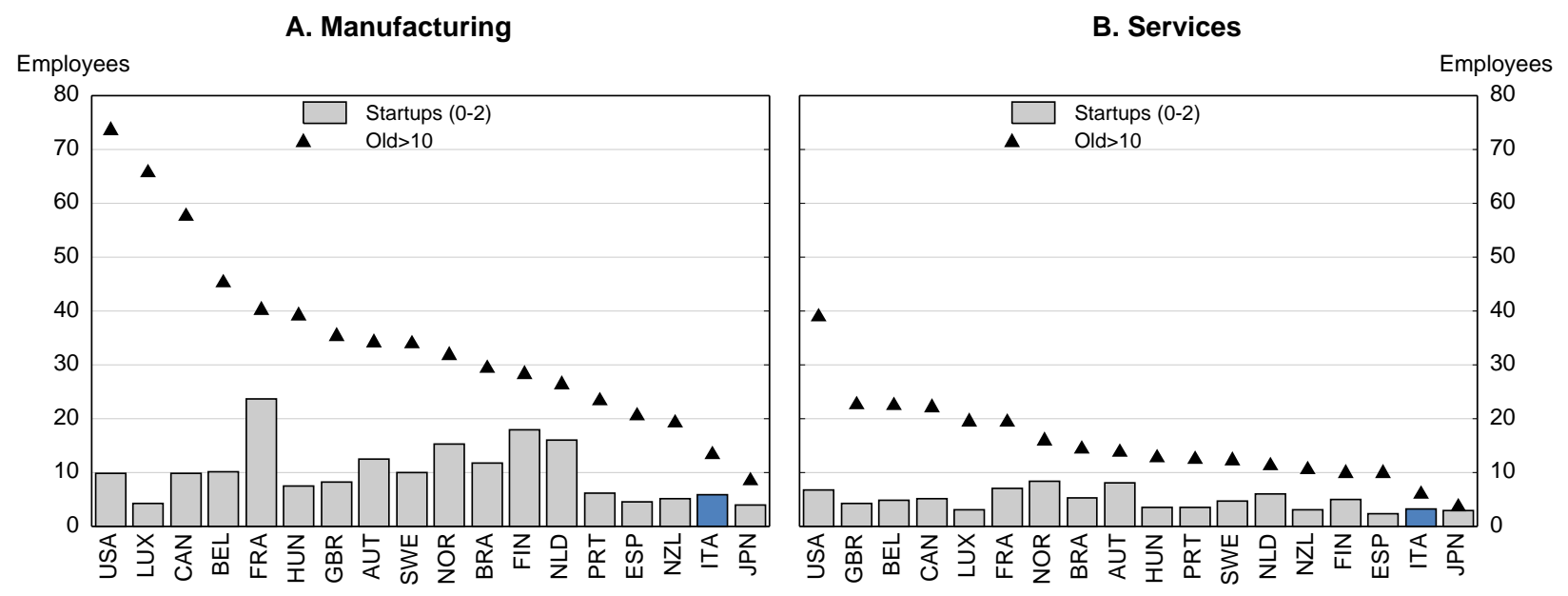

Note: The graph reports the average size of start-up firms (from 0 to 2 years old) and firms more than 10 years old, as the average over the available years. The period covered is 2001-2011 for Belgium, Canada, Finland, Hungary, the Netherlands, the United Kingdom and the United States; 2001-2010 for Austria, Brazil, Spain, Italy, Luxembourg, Norway and Sweden; 2001-2009 for Japan and New Zealand; 2001-2007 for France; and 2006-2011 for Portugal. Sectors covered are: manufacturing and non-financial business services. Owing to methodological differences, figures may deviate from officially published national statistics. For Japan data are at the establishment level, for other countries at the firm level. Data for Canada refer only to organic employment changes and abstract from merger and acquisition activity.

OECD calculations based on firm level data from the ORBIS-Patstat Database for the non-farm business sector. See Andrews, Criscuolo and Menon (2014).

Source: Criscuolo, Gal and Menon (2014), "The Dynamics of Employment Growth: New Evidence from 18 Countries”, OECD Science, Technology and Industry Policy Papers No.14.

61. The resource allocation mechanism is impaired, as it does not channel resources to the most productive firms. Andrews and Cingano (2014) show that more productive firms are less likely to account for a larger share of employment in Continental and Southern European countries, including Italy (Figure 9). Andrews et al. (2014) show that the extent to which capital flows to innovative firms, measures by a change in patent stock, is found to be very low in Italy (Figure 20). 
Figure 20. Resources do not flow to more innovative firms

Additional capital to a firm that increases its patent stock by $10 \%$; selected OECD countries (2002-2010)

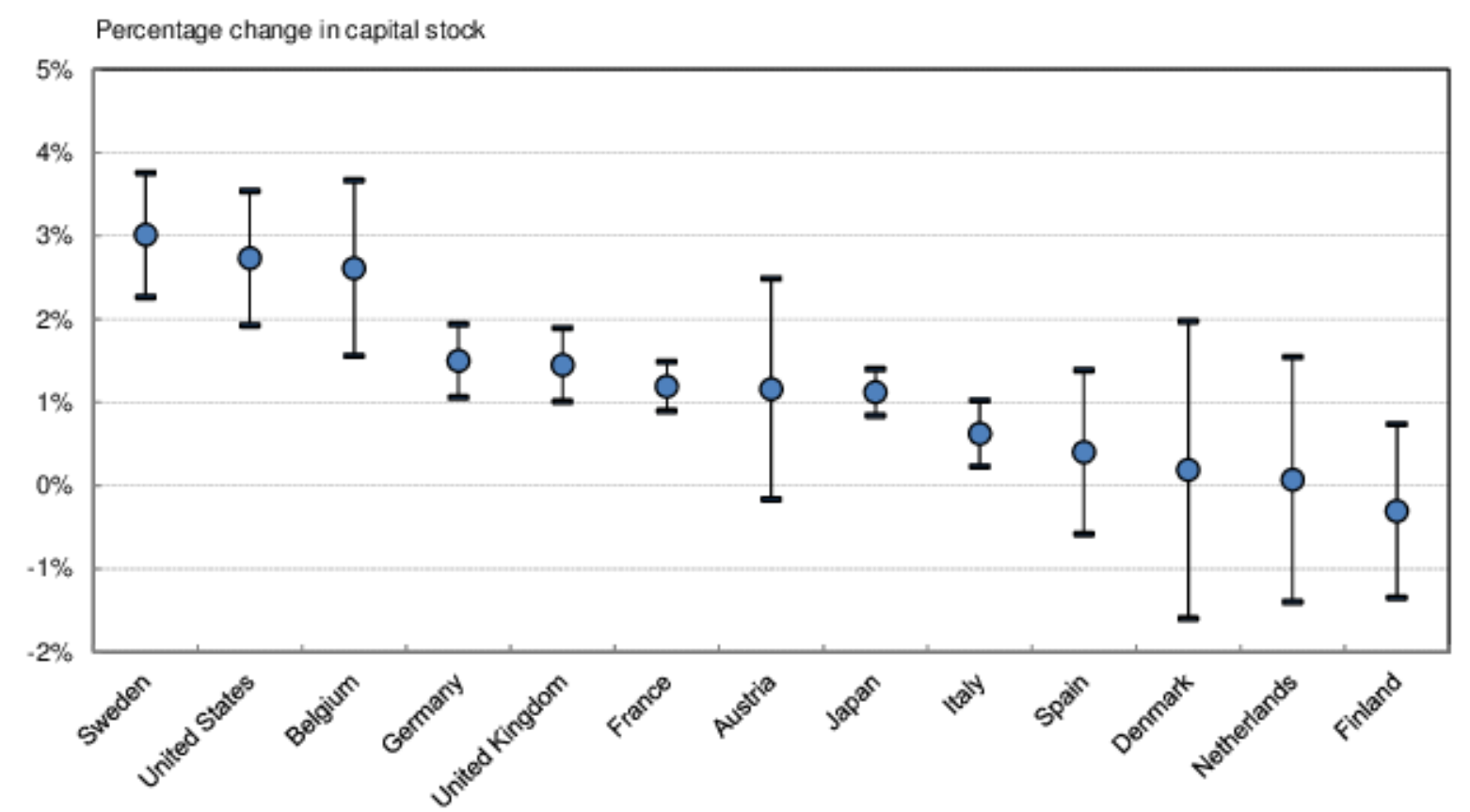

Note: The chart shows the country-specific point estimate as well as the $90 \%$ confidence interval. These estimates are obtained from the following fixed-effects regressions:

$\ln Y_{i, s, c, t}=\beta_{1} \ln \left(\right.$ Pat $\left.S_{i, s, c, t}\right)+\varphi_{i}+\mu_{s, c, t}+\varepsilon_{i, s, c, t}$

where $Y$ is the capital for firm I, in sector $s$, in country $c$, at time $t$; Pat $S$ is the patent stock of firm $i$. The specification also includes firm fixed effects and industry*country*year fixed effects. To obtain the country-specific estimate, Pat $S$ is interacted with various dummy variables for each country.

The model was estimated based on firm-level data from the ORBIS-Patstat Database for the non-farm business sector.

Source: Andrews, D., C. Criscuolo and C. Menon (2014), "Do Resources Flow to Patenting Firms?: Cross-Country Evidence from Firm Level Data", OECD Economics Department Working Papers, No. 1127, OECD Publishing.

62. These findings are consistent with the fact that most firms in Italy are very small, old, and not very productive. As a role of public policy, a series of OECD papers (e.g. Andrews et al., 2014) identifies in particular the effects of product market regulation, trade and investment restrictions, employment protection legislation, and bankruptcy legislation.

63. Product market reforms have been in progress in terms of legislations per se. The OECD's Product Market Regulation (PMR) indicators have improved significantly, in the areas of state control, involvement in business operations, and explicit barriers to the trade and investment since 2008, although there has been no real movement for public ownership. Regulation is now close to the OECD average, in some domains much better than it, with the exception of scope of state-owned enterprises which remains high.

64. However, the problems on implementation and enforcement exist. Other indicators of business conditions show a different picture for Italy: for example the World Bank's "Doing Business" ranks Italy at a lower position. The survey, while somewhat overlapping with the PMRs in terms of laws and regulations as written, analyses business conditions from different perspective, as most indicators are based on the cost of and time taken for stylised business operations and including a measure of the efficiency of 
courts. These facts point to the importance of implementation and enforcement which could be more relevant problems for Italy (OECD, 2013a;).

65. The focus on implementation by the current government leads to some concrete actions. For example, in the "Simplification Agenda 2015-2017", the government, regions and local authorities have established a shared commitment to the implementation of simplification measures in five areas: digital citizenship; health and welfare; tax law; construction and enterprise. For each sector, the Agenda identifies actions, responsibilities, deadlines and expected results and, for each action, a detailed time schedule provides manner and timing of implementation.

66. The bankruptcy regime has been slightly improved due to recent reforms, but still weighs on businesses. The average time to close a business has been reduced to 1.8 years, close to the OECD average. However exit costs following business failure are still high, estimated at $22 \%$ of the estate's value against the OECD average of $9 \%$. The recovery rate from an insolvent firm is estimated to be $62.7 \%$, well below the OECD average, which reduces firms' access to credit.

\section{More favourable environment for innovation}

67. The current state of corporate finance is overall not favourable for firms' growth and innovation in particular. The very low share of equity capital in firms' financing is itself a problem for potentially productive firms currently facing financial constraints. This problem is more relevant for R\&D activities. Firms' internal resources are the primary source of R\&D financing, due to the high degree of risk and the information asymmetries associated with innovative activity. Over $80 \%$ of $R \& D$ spending by firms is internally funded in all four large European countries, according to the Bruegel Institute. In Italy the second biggest source of financing is bank loans (slightly less than $10 \%$ of R\&D spending), whereas in the United Kingdom, this proportion is much lower (1\%) and equity plays a more important role. The role of venture capital funds - investor that provide early-stage financing as well as consulting for firms in high growth potential sectors - or business angels, private investors operating on a smaller scale with respect to venture capital funds, is extremely limited in Italy.

68. Financial incentives for innovation should be reshaped, since tax credit system seems to oversubsidise incumbent firms at the expense of dynamic young firms. In Italy, R\&D tax credits are neither refundable nor contain carry-over provisions. The design of such schemes may provide less assistance to young firms which are typically in a loss position in the early years of an R\&D project, reducing effective rate of the tax subsidy to R\&D (Elschner et al., 2011). Also, R\&D tax credits should be more closely tied to the most productive sources of innovation to improve targeting of government subsidies. Thus, more emphasis could be put on selective subsidies through grants, loans and prizes, based on competitive, objective and transparent selection. Colombo et al. (2011) shows that selective subsidies are likely to be more beneficial to new technology-based firms than automatic ones.

\section{Institutions and Job quality}

69. A recent OECD study sheds light on job quality from the view point of well-being (OECD, 2014b). The study defines job quality along the three aspects: earnings quality, labour market security, and quality of the working environment (Table 3). The results show that those countries which are ranked high in terms of the quantity of employment tend to be ranked high also in terms of job quality. According to these criteria, the reforms in process are expected to improve job quality overall:

- Reduction in EPL as well as PMR leads to higher earnings level in the aggregate through higher productivity; 
- Tackling dualism contributes to reducing earnings inequality;

- A EPL reform usually results in higher probability of unemployment and but also shortens unemployment spells, due to higher probability of re-employment, and the anxiety on long unemployment spells seems to dominate in general (OECD, 2014b);

- Extended unemployment benefit coverage would help to reduce labour market insecurity;

- Flexible wage may result in widening earnings disparity, reflecting differences in skills or innate ability, but it would be better than the situation where inequality is embedded due to institutional factors, that is, high wage for those who protected at the expense of those who stay at the margins of the labour market.

Table 3. Broad outcome measures of job quality and their subcomponents

\begin{tabular}{|c|c|c|}
\hline Dimensions & $\begin{array}{l}\text { Aggregate outcome } \\
\text { measure of job quality }\end{array}$ & $\begin{array}{l}\text { Subcomponents } \\
\text { (at the individual level) }\end{array}$ \\
\hline $\begin{array}{l}\text { Earnings } \\
\text { quality }\end{array}$ & $\begin{array}{l}\text { Earnings index taking into } \\
\text { account both earnings } \\
\text { level and its distribution } \\
\text { (inequality) }\end{array}$ & Level of earnings \\
\hline \multirow{2}{*}{$\begin{array}{l}\text { Labour market } \\
\text { security }\end{array}$} & \multirow{2}{*}{$\begin{array}{l}\text { Expected earnings loss } \\
\text { associated with } \\
\text { unemployment }\end{array}$} & $\begin{array}{l}\text { Unemployment risk } \\
\text { - Risk of becoming unemployed } \\
\text { - Expected duration of unemployment }\end{array}$ \\
\hline & & $\begin{array}{l}\text { Insurance against unemployment risk } \\
\text { - Eligibility to unemployment benefits } \\
\text { - Generosity of benefits (replacement rates) }\end{array}$ \\
\hline \multirow{2}{*}{$\begin{array}{l}\text { Quality of the } \\
\text { working } \\
\text { environment }\end{array}$} & \multirow{2}{*}{$\begin{array}{l}\text { Proportion of workers } \\
\text { experiencing job strain } \\
\text { (i.e. imbalance between } \\
\text { work stressors and } \\
\text { workplace resources) }\end{array}$} & $\begin{array}{l}\text { Work-related stress factors } \\
\text { - Time pressure at work } \\
\text { - Exposure to physical health risk factors } \\
\text { - Workplace intimidation }\end{array}$ \\
\hline & & $\begin{array}{l}\text { Support and resources to accomplish job } \\
\text { duties } \\
\text { - Work autonomy and learning opportunities } \\
\text { - Good management practices } \\
\text { - Good workplace relationships }\end{array}$ \\
\hline
\end{tabular}

Source: OECD Employment Outlook 2014, Chapter 3

70. Economic performance as well as job satisfaction can be improved by designing better institutions. It is well-known that the set of institutions interact with shocks, which generates different economic and labour outcomes (Blanchard and Wolfers, 2000; Nickell et al., 2003). The allocation of the factors of production and the distribution of income can be hampered by worse performing institutions, which is often embedded by vested interests of certain groups. Instead, a set of better institutions facilitate the economy to reap more benefits from business opportunities; firms react promptly more qualityimproving innovations and adoption of leading technologies, while workers depend less on wealth and/or social benefits, otherwise costly for businesses as the reservation wage becomes higher all else equal (Phelps, 1994; Fitoussi et al., 2000). Phelps and Zoega (2013) also find that job satisfaction is higher where a set of institutions fostering equality of opportunities and upward mobility provide better economic performance. More and better quality jobs would be produced in such a truly inclusive environment, conducive to higher living standard. 
ECO/WKP(2015)84

\section{Box 4. Policy Recommendations for job creation and job quality}

Fully roll-out the new standard contract for new hires, with employment protection rising with job tenure, while grandfathering existing contracts.

Ensure that access to courts is preserved only in case of invalid and discriminatory dismissals (on the ground of race, gender, religion and disability), and some specific disciplinary dismissals.

Carefully monitor the impact of the labour market reforms in reducing the recourse to legal action. Consider generalising automatic severance pay linked to length of service in case of dismissal for objective reasons (redundancies) at affordable levels no higher than the OECD average.

Fully implement the unified unemployment benefit system. Require recipients to actively seek work, and to accept employment or training when offered.

Change the composition of spending on active labour-market policy: target training programmes to those who need them most, especially among youth, while reinforcing career orientation and job placement services; tailor assistance to job seekers according to their specific situation.

Encourage social partners to allow modification of national wage agreements at the firm level, through agreement with representatives of a majority of the firm's employees.

Legal minimum wage should be set flexibly across regions, taking account of different productivity.

Encourage female labour force participation with more flexible working-hours arrangements, and promote wider provision of good quality care for children and the elderly.

Avoid job mismatch taking into account occupational demands and orienting students accordingly. Strengthen VET to provide more professional experience and to be coordinated with industry needs.

Continue reforming the product market to lower barriers to entry in the regulated professions and to promote competition in all areas. Ensure a level playing field for new entrants in terms of financial incentives for innovations. 


\section{REFERENCES}

Adalet McGowan, M. and D. Andrews (2015), "Skill Mismatch and Public Policy in OECD countries", OECD Economics Department Working Papers, No. 1209, OECD Publishing.

Aidt, T.S. and Z. Tzannatos (2008), "Trade Unions, Collective Bargaining and Macroeconomic Performance: A Review”, Industrial Relations Journal, Vol. 39, No. 4, pp. 258-295.

Allio, L. and N. Rangone (2015), "Anti-corruption and transparency initiatives for a more accountable and efficient public administration in Italy," OECD Economics Department Working Papers, forthcoming.

Andrews, D and F. Cingano (2014), "Public Policy and Resource Allocation: Evidence from firms in OECD countries", Economic Policy 29(78), pp. 253-296.

Andrews, D., C. Criscuolo and C. Menon (2014), "Do Resources Flow to Patenting Firms?: Cross-Country Evidence from Firm Level Data", OECD Economics Department Working Papers, No. 1127, OECD Publishing.

Bassanini, A. and R. Duval (2009), "Unemployment, Institutions, and Reform Complementarities: Reassessing the Aggregate Evidence for OECD Countries", Oxford Review of Economic Policy, Vol. 25, pp. 40-59.

Blanchard, O., and J. Wolfers (2000), "The Role of Shocks and Institutions in the Rise of European Unemployment : The Aggregate Evidence," The Economic Journal, 110 : C1-33.

Boeri, T. (2011), "Institutional Reforms and Dualism in European Labor Markets", in O. Ashenfelter and D. Card (eds.), Handbook of Labor Economics, Vol. 4b, North Holland, Amsterdam.

Boeri, T., A. Ichino, and E. Moretti (2014), "Housing, Real Inequality and Mobility", Presentation at XVI Annual Conference of the Fondazione Rodolfo De Benedetti.

Boeri, T. and J. Jimeno (2005), "The Effects of Employment Protection: Learning from Variable Enforcement”, European Economic Review, Vol. 49, pp. 2057-2077.

Caballero, R.J., K. N. Cowan, E. M. R. A. Engel, and A.Micco (2004), "Effective Labor Regulation and Microeconomic Flexibility", Cowles Foundation Discussion Papers, No. 1480.

Calmfors, L. and J. Driffill (1988), "Bargaining Structure, Corporatism and Macroeconomic Performance", Economic Policy, Vol. 3, No. 6, pp. 13-62.

Colombo, M.G., L. Grilli, and S. Murtinu (2011), "R\&D Subsidies and the Performance of High-Tech Startups", Economics Letters, 112(1), pp. 97-99.

Criscuolo, C., P. Gal and C. Menon (2014), "The Dynamics of Employment Growth: New Evidence from 18 Countries", OECD Science, Technology and Industry Policy Papers No.14.

Elschner, C., C. Ernst, G. Licht and C. Spengel (2011), "What the Design of an R\&D Tax Incentive Tells About is Effectiveness: A Simulation of R\&D Tax Incentives in the European Union", Journal of Technological Transfer 36, pp. 233-256. 
Fitoussi, J. P., D. Jestaz, E. S. Phelps, and G. Zoega (2000), "Roots of the Recent Recoveries: Labor Reforms or Private Sector Forces?," Brookings Papers on Economic Activity, 2000 (1): 237-91.

Higuchi, Y. (2013), "The Dynamics of Poverty and the Promotion of Transition from Non-Regular to Regular Employment in Japan: Economic Effects of Minimum Wage Revision and Job Training Support", Japanese Economic Review, Vol. 64 (2), pp. 147-200.

Jin, Y., R. Fukahori, and H. Morgavi (2015), "Identifying the Most Cost Effective Active Labour Market Policies for Different Job Seekers", OECD Economics Department Working Papers, forthcoming, OECD Publishing.

Kugler, A. and G. Pica (2008), "Effects of Employment Protection on Worker and Job Flows: Evidence from the 1990 Italian Reform”, Labour Economics, Vol. 15, pp. 78-95.

Leonardi, M. and G. Pica (2013), "Who Pays for It? The Heterogeneous Wage Effects of Employment Protection Legislation", Economic Journal, Vol.123, pp. 1236-1278.

Ministry of Labour (2014), Il primo anno di applicazione della legge 92/2012.

Mortensen, D.T. and C.A. Pissarides (1999), "Unemployment Responses to 'Skill Biased' Shocks: TheRole of Labor Market Policy”, Economic Journal, No. 109, pp. 242-265.

Mortensen, D.T. and C.A. Pissarides (1994), "Job Creation and Job Destruction in the Theory ofUnemployment”, Review of Economic Studies, Vol. 61, pp. 397-415.

Nickell, S., L. Nunziata, W. Ochel and G. Quintini (2003), "The Beveridge Curve, Unemployment, and Wages in the OECD from the 1960s to the 1990s," in P. Aghion, R. Frydman, J. Stiglitz, M. Woodford, eds., Knowledge, Information, and Expectations in Modern Macroeconomics, Princeton: Princeton University Press.

OECD (2004), Employment Outlook 2004, OECD Publishing.

OECD (2006), Employment Outlook 2006 Boosting Jobs and Incomes, OECD Publishing.

OECD (2009), OECD Economic Surveys: Italy, OECD Publishing.

OECD (2010), Jobs for Youth: off to a good start?, OECD Publishing.

OECD (2011a), Divided we stand: why inequality keeps rising, OECD Publishing.

OECD (2011b), Doing Better for Families, OECD Publishing.

OECD (2012), Closing the Gender Gap - Act Now, OECD Publishing.

OECD (2013a), OECD Economic Surveys: Italy, OECD Publishing.

OECD (2013b), Employment Outlook 2013, OECD Publishing.

OECD (2014a), OECD Economic Outlook November 2014, OECD Publishing.

OECD (2014b), Employment Outlook 2014, OECD Publishing. 
OECD (2014c), OECD Economic Surveys: Spain, OECD Publishing.

OECD (2014d), Policy Challenges for the next 50 years. OECD Economic Policy paper, July 2014, No. 9.

OECD, ILO, IMF and World Bank (2014), "Achieving stronger growth by promoting a more genderbalanced economy", Report prepared for the G20 Labour and Employment Ministerial Meeting Melbourne, Australia, 10-11 September 2014.

Pissarides, C.A. (2000), Equilibrium Unemployment Theory, second edition, The MIT Press.

Phelps, E.S. (1994), Structural Slumps, Cambridge, Massachusetts, and London: Harvard University Press.

Phelps, E.S., and G. Zoega (2013), "Corporatism and Job Satisfaction", Journal of Comparative Economics, Vol. 41, pp. 35-47.

Rusticelli, E. (2015) "Rescuing the Phillips Curve: Making Use of Long-term Unemployment in the Measurement of the NAIRU", forthcoming in OECD Journal: Economics Studies.

Schivardi, F. and R. Torrini (2008), "Identifying the Effects of Firing Restrictions Through SizeContingent Differences in Regulation”, Labour Economics, Vol. 15, pp. 482-511.

Sestito, P. (2004), "Economic Convergence across and within Europe: is there a puzzle", presentation at the 2004 Brussels Economic Forum, 22-23 April.

Thévenon. O, N Ali, W Adema and A. Salvi del Pero (2012), "Effects of Reducing Gender Gaps in Education and Labour Force Participation on Economic Growth in the OECD", OECD Social, Employment and Migration Working Papers No. 138, OECD Publishing. 